\title{
GEOLOGY AND MINERALOGY OF THE LITTLE NAHANNI RARE-ELEMENT GRANITIC PEGMATITES, NORTHWEST TERRITORIES
}

\author{
LEE A. GROAT $\$$ \\ Department of Earth and Ocean Sciences, University of British Columbia, Vancouver, British Columbia V6T 1Z4, Canada \\ THOMAS MULJA ${ }^{\mathbb{I}}$ \\ 3709 Rutherford Crescent, North Vancouver, British Columbia V7N 2C6, Canada \\ MARK H.F. MAUTHNER $\ddagger$ \\ Department of Earth and Ocean Sciences, University of British Columbia, Vancouver, British Columbia V6T 1Z4, Canada
}

T. SCOTT ERCIT

Research Division, Canadian Museum of Nature, P.O. Box 3443, Station D, Ottawa, Ontario K1A OE8, Canada

MATI RAUDSEPP

Department of Earth and Ocean Sciences, University of British Columbia, Vancouver, British Columbia V6T 1Z4, Canada

ROBERT A. GAULT

Research Division, Canadian Museum of Nature, P.O. Box 3443, Station A, Ottawa, Ontario K1A OE8, Canada

H. ANDREW ROLLO

Department of Earth and Ocean Sciences, University of British Columbia, Vancouver, British Columbia V6T 1Z4, Canada

ABSTRACT

The Little Nahanni rare-element granitic pegmatite group (LNPG; $c a .82 \mathrm{Ma}$ ) in the western part of the Northwest Territories, occurs as subparallel dike swarms over an area of $\sim 11 \times 5 \mathrm{~km}$ in the walls of a series of cirques dominated by schists of the Upper Proterozoic Hyland Group. These pegmatite bodies, up to a few meter wide, are divisible into spodumene-bearing and spodumenefree varieties that occur close together; some dikes split into these two variants. The two types are mineralogically similar. Both contain K-feldspar, plagioclase, quartz, mica (muscovite to lepidolite), columbite-group minerals, cassiterite, tourmaline, beryl, lithiophilite and garnet; they differ in the abundance of mica and accessory phases. The spodumene-free pegmatites have more mica, particularly lepidolite, than the spodumene-bearing variety. Apatite and montebrasite occur primarily in the former, whereas most lithiophilite is present in the latter. Sparse galena, titanian rutile, fluorite and helvite are also found in both variants. Subsolidus phases are zeolite-group minerals, microlite, and secondary phosphate minerals such as triploidite. Internal zoning in both pegmatites varies from complex to symmetrical. Where well developed, the zoning is typical from border through wall and intermediate to core zone. Quartz and the feldspars occur throughout the dikes. Micas and columbite-group minerals initially increase from the border to the wall zone and subsequently decrease toward the core, whereas tourmaline becomes less abundant toward the core. Spodumene and cassiterite first appear in the wall zone and become more abundant toward the core zone, whereas the reverse is true for beryl. Phosphate minerals exist mainly in the intermediate zone of the lepidolite pegmatites, and

E-mail address: 1groat@eos.ubc.ca

II Present address: School of Geology, Oklahoma State University, 105 Noble Research Center, Stillwater, Oklahoma 74078, U.S.A.

$\doteqdot \quad$ Present address: Pacific Mineral Museum, 848 West Hastings Street, Vancouver, British Columbia V6C 1C8, Canada.

$\dagger$ Present address: Department of Geological Sciences and Geological Engineering, Queen's University, Kingston, Ontario K7L 3N6, Canada. 
lithiophilite in the spodumene pegmatites. Garnet remains a trace mineral in all zones, with the exception of the core zone. where it is absent. Sporadic small cavities containing quartz, $\mathrm{K}$-feldspar, apatite, $\mathrm{Mg}$-rich beryl, elbaite and calcite are present in some dikes. The composition of the rock-forming minerals in both types of pegmatite is similar. An example of the chemical evolution of the minerals is shown by tourmaline, which becomes richer in $\mathrm{Al}$ and $\mathrm{Li}$, but poorer in $\mathrm{Mg}$, and shows decreasing $\mathrm{Na} /(\mathrm{Na}+$ vacancy) and increasing $\mathrm{Al} /(\mathrm{Al}+\mathrm{Fe})$ values from the schist to the inner (wall + intermediate) zone of the pegmatite. These trends, together with the changes in the abundances and paragenetic sequence of the major minerals, are interpreted to reflect an increase in the $\mathrm{Rb}, \mathrm{Cs}, \mathrm{Li}, \mathrm{F}, \mathrm{P}, \mathrm{Be}$, and Ta contents, and a decrease in the contents of $\mathrm{Mg}, \mathrm{Fe}$, and $\mathrm{B}$ contents, in the felsic liquids during crystallization.

Keywords: spodumene, lepidolite, granitic pegmatite, chemical evolution of minerals, Nahanni, Northwest Territories.

\section{SOMMAIRE}

Le groupe de pegmatites granitiques à éléments rares de Little Nahanni (LNPG; $c a .82 \mathrm{Ma}$ ), situé dans le secteur ouest des Territoires du Nord-Ouest, se présente sous forme d'essaims de filons subparallèles sur une superficie d'environ $11 \times 5 \mathrm{~km}$ dans les parois de cirques, où affleurent les schistes du groupe de Hyland, d'âge protérozoïque supérieur. Ces filons, atteignant une largeur de quelques mètres, se divisent littéralement dans certains cas en deux variétés contigües, une à spodumène et l'autre qui en est dépourvue. Du point de vue minéralogique, les deux variétés se ressemblent: les deux contiennent feldspath potassique, plagioclase, quartz, mica (muscovite à lépidolite), minéraux du groupe de la columbite, cassitérite, tourmaline, béryl, lithiophilite et grenat; ils diffèrent selon l'abondance et la nature du mica et des phases accessoires. Les venues dépourvues de spodumène contiennent plus de mica, en particulier la lépidolite, que les filons à spodumène. L'apatite et la montébrasite sont surtout développées dans les filons sans spodumène, tandis que la plupart des exemples de lithiophilite se trouvent dans les filons à spodumène. Des proportions infimes de galène, rutile titanifère, fluorite et helvite sont présentes dans les deux variantes. Les minéraux d'origine subsolidus sont les minéraux du groupe des zéolites, microlite, et des phosphates secondaires comme la triplö̈dite. La zonation interne des deux types de pegmatite varie de complexe à symétrique. Dans les cas où elle est bien développée, cette zonation est typique à partir de la paroi externe, en passant par les zones extérieures et intermédiaires, jusqu'au centre. Quartz et les feldspaths sont répandus dans chaque filon. La proportion des micas et des minéraux du groupe de la columbite augmente d'abord de la bordure vers la zone externe, et diminue ensuite vers le centre, tandis que celle de la tourmaline diminue progressivement vers le centre. Le spodumène et la cassitérite apparaissent d'abord dans la zone externe, et leur incidence augmente vers le centre, tandis que l'inverse décrit la distribution du béryl. Les minéraux phosphatés se trouvent surtout dans la zone intermédiaire des pegmatites à lépidolite, et la lithiophilite, dans les pegmatites à spodumène. Le grenat est à l'état de traces dans chaque zone, à l'exception du centre, où il est absent. De petites cavités, distribuées sporadiquement, et contenant quartz, feldspath potassique, apatite, béryl riche en $\mathrm{Mg}$, elbaïte et calcite, sont présentes dans certains filons. Du point de vue de la composition des minéraux, les deux types de pegmatite se ressemblent. L'évolution des minéraux est illustrée avec la tourmaline, qui devient plus riche en $\mathrm{Al}$ et $\mathrm{Li}$, mais plus pauvre en $\mathrm{Mg}$, et accuse une diminution du rapport $\mathrm{Na} /(\mathrm{Na}+\mathrm{lacune})$ et une augmentation du rapport $\mathrm{Al} /(\mathrm{Al}+\mathrm{Fe})$ à partir de l'exocontact dans les schistes vers les zones internes de la pegmatite. Ces tendances, de même que les changements progressifs en abondance et en séquence paragénétique des minéraux majeurs, témoigneraient d'une augmentation de la teneur en $\mathrm{Rb}, \mathrm{Cs}, \mathrm{Li}, \mathrm{F}, \mathrm{P}, \mathrm{Be}$, et Ta, et d'une réduction de la teneur en $\mathrm{Mg}$, Fe, et $\mathrm{B}$, dans la fraction liquide au cours de sa cristallisation.

(Traduit par la Rédaction)

Mots-clés: spodumène, lépidolite, pegmatite granitique, évolution chimique des minéraux, Nahanni, Territoires du Nord-Ouest.

\section{INTRODUCTION}

Rare-element-bearing granitic pegmatites, characterized by high contents of $\mathrm{H}_{2} \mathrm{O}, \mathrm{Li}, \mathrm{B}, \mathrm{F}$, and $\mathrm{P}$, uncommon mineralogy, and extreme textural variations, solidify under chemical and physical conditions that differ greatly from the conventional paths of crystallization of normal felsic melts (London 1995). Experimental investigations (London et al. 1989, London 1999, Vekler \& Thomas 2002, Vekler et al. 2002) have proposed a number of mechanisms (crystallization and zone refinement, liquid immiscibility) by which the internal structure of pegmatites can be formed. Theoretical studies by Webber et al. (1999) indicated that crystallization of aplite-pegmatite dikes involved mul- tiple mechanisms. Despite these advances, mineralization processes remain poorly understood (Vekler \& Thomas 2002). Moreover, what has been lacking is correlation between certain mineralogical zones and particular kinds of mechanisms.

Another actively debated topic is the petrogenesis of these unique rocks. Černý \& Meintzer (1988), armed with an extensive geological and geochemical database, advocated extreme fractionation of crystals as the most likely viable mechanism for the derivation of rare-element pegmatites from a differentiating felsic melt. However, the spatial and petrochemical continuum between pegmatites and granite as an evidence of a comagmatic relationship has been questioned recently by Tomascak et al. (1998) on the basis of $\mathrm{Sm}-\mathrm{Nd}$ isotope systemat- 
ics. Furthermore, in an idealized model of a rare-element granite - pegmatite complex, the pegmatites vary regionally from beryl-bearing in or near the parental pluton, through beryl-spodumene-bearing in the country rock, to spodumene- and lepidolite-bearing furthest from the pluton (Trueman \& Černý 1982). Whereas this regional zonation exists at some localities (Mulja et al. 1995, Černý 1992), many pegmatite fields contain only the spodumene- or lepidolite-bearing pegmatites with or without granitic bodies (O'Connor et al. 1991, Stewart 1978). Thus, could the anatectic model of Stewart (1978) for lithium pegmatites, which has been sidelined in favor of the fractional crystallization model, be applicable to some spodumene pegmatites?

The rare-element-bearing pegmatites of the Little Nahanni Pegmatite Group (LNPG), in the Northwest Territories, consist mainly of spodumene-bearing pegmatite dikes, with subordinate spodumene-free (mainly lepidolite-rich) dikes. Beryl pegmatites are absent. The pegmatites are hosted by metamorphic rocks, and no immediate large granitic bodies have been located despite extensive exposures of bedrock. They are well exposed (covering an area of about $11 \times 5 \mathrm{~km}$ ) and undeformed, and have been explored for $\mathrm{Li}, \mathrm{Sn}$, and Ta. The LNPG is therefore an excellent natural laboratory in which to explore the aforementioned issues on the nature and origin of rare-element pegmatites. In this first contribution on the petrogenesis of the Little Nahanni pegmatites, we report on the geology, mineralogy, and mineral chemistry of the pegmatites.

\section{Regional Geology and Metallogeny}

The Little Nahanni Pegmatite Group (LNPG) is 47 $\mathrm{km}$ northwest of Tungsten in the Logan Mountains, Northwest Territories $\left(62^{\circ} 12^{\prime} \mathrm{N}, 128^{\circ} 50^{\prime} \mathrm{W}\right.$, Fig. 1). The Group is in the Upper Hyland Lake segment (105I/2, 1:50,000) of the Nahanni map area (105I, 1:250,000). The regional geology of the LNPG was described by Gordey \& Anderson (1993), from which the following summary is adapted. From the late Precambrian to middle Devonian, a northwest-trending facies belt consisting of turbiditic sandstone, deep-water limestone, shale and chert (the Selwyn Basin) developed in the map area. In the late Devonian and Mississippian, turbiditic quartz-chert sandstone and chert-pebble conglomerate were deposited. Early Mississippian to Triassic sedimentation was dominated by shale, chert, minor sandstone, and siltstone deposited on a shallow marine shelf.

Regional Jurassic-Cretaceous deformation resulted in northwest-trending folds and minor thrust faults. The incompetent strata of the Selwyn Basin were deformed into small- to large-scale open to tight folds with associated axial-plane cleavage. The regional metamorphic grade is subgreenschist facies.

The epizonal to mesozonal Selwyn Plutonic Suite (ca. $100 \mathrm{Ma}$ ) cross-cuts the regional structure (Fig. 1), and is divisible into: (1) hornblende-bearing plutons, (2) peraluminous biotite-muscovite plutons, and (3) transitional plutons with compositions intermediate to those of (1) and (2). The geographically closest granitic intrusions to the LNPG are (from east to west) the Rudi (4.7 $\left.\mathrm{km}^{2}, 84-87 \mathrm{Ma}\right)$, Cac $\left(1.9 \mathrm{~km}^{2}\right)$, and Lened $\left(12.3 \mathrm{~km}^{2}\right.$, $93 \mathrm{Ma}$ ) plutons; the latter is within $15 \mathrm{~km}$ of the northeastern part of the Group. All are two-mica plutons with common peraluminous dikes, and are associated with W- and base-metal skarns. Contact aureoles about plutonic rocks are typically andalusite- and biotite-bearing; the first appearance of andalusite occurs within $0.5 \mathrm{~km}$ of intrusive contacts.

From a metallogenic viewpoint, the Little Nahanni Li-Ta-Sn-bearing granitic pegmatites constitute the youngest felsic intrusion and mineralization event (81.6 $\pm 0.5 \mathrm{Ma}$, Mauthner et al. 1995) reported for the Selwyn Basin area. The earliest recorded granite-related metallic deposits in the area include the $\mathrm{W}$-skarns of the early Silurian ( 420 to $440 \mathrm{Ma}$ ) Howard Pass and late Devonian to Mississippian ( 370 to $320 \mathrm{Ma}$ ) MacMillan Pass districts. There seems to be a hiatus in magmatic-hydrothermal ore genesis, as the next period of mineralization did not occur until late Cretaceous, when igneous activity produced skarn deposits ranging from $\mathrm{W}$ - and $\mathrm{Cu}$-bearing in the east, through $\mathrm{Zn}(\mathrm{Pb}, \mathrm{W})$ - and $\mathrm{W}(\mathrm{Mo})-$ bearing, to Sn-bearing in the west (Fig. 1). The trend of the skarn types appears to be parallel to the NNW- to SSE-trending Tintina strike-slip fault. Two examples of the W-Cu skarns are the well known CanTung (94 Ma) and MacTung (89 to $90 \mathrm{Ma}$ ) deposits.

\section{Geology of the Little Nahanni Pegmatites}

The oldest rocks in the immediate area of the LNPG are the Precambrian to Lower Cambrian sedimentary rocks of the Hyland Group, which is subdivided into the Yusezyu and Narchilla formations (Gordey \& Anderson 1993; Fig. 2). The Yusezyu Formation hosts the pegmatites and consists of a thick succession of quartz sandstone, schist and shale. Minor limestone forms a thin discontinuous layer at the top of the formation, which is overlain sharply and conformably by maroon or dark grey shale of the Narchilla Formation. Near the pegmatites, the rocks are metamorphosed to subgreenschist facies. The schist shows a strong foliation that is subtly kinked and displaced by the appearance of andalusite, biotite, chloritoid, and staurolite porphyroblasts. The andalusite porphyroblasts appear to be coarser (to $2.5 \mathrm{~cm}$ ) in the northernmost parts of the Group. Cordierite porphyroblasts with biotite inclusions and muscovite, chlorite and tourmaline grains along the edges are found in some parts of the schist. Staurolite porphyroblasts show curved trails of inclusions and biotite inclusions similar to those in the groundmass. Growth of cordierite and staurolite porphyroblasts has consumed chlorite.

Contacts between the pegmatite and the country rocks are typically sharp; locally, they are irregular de- 


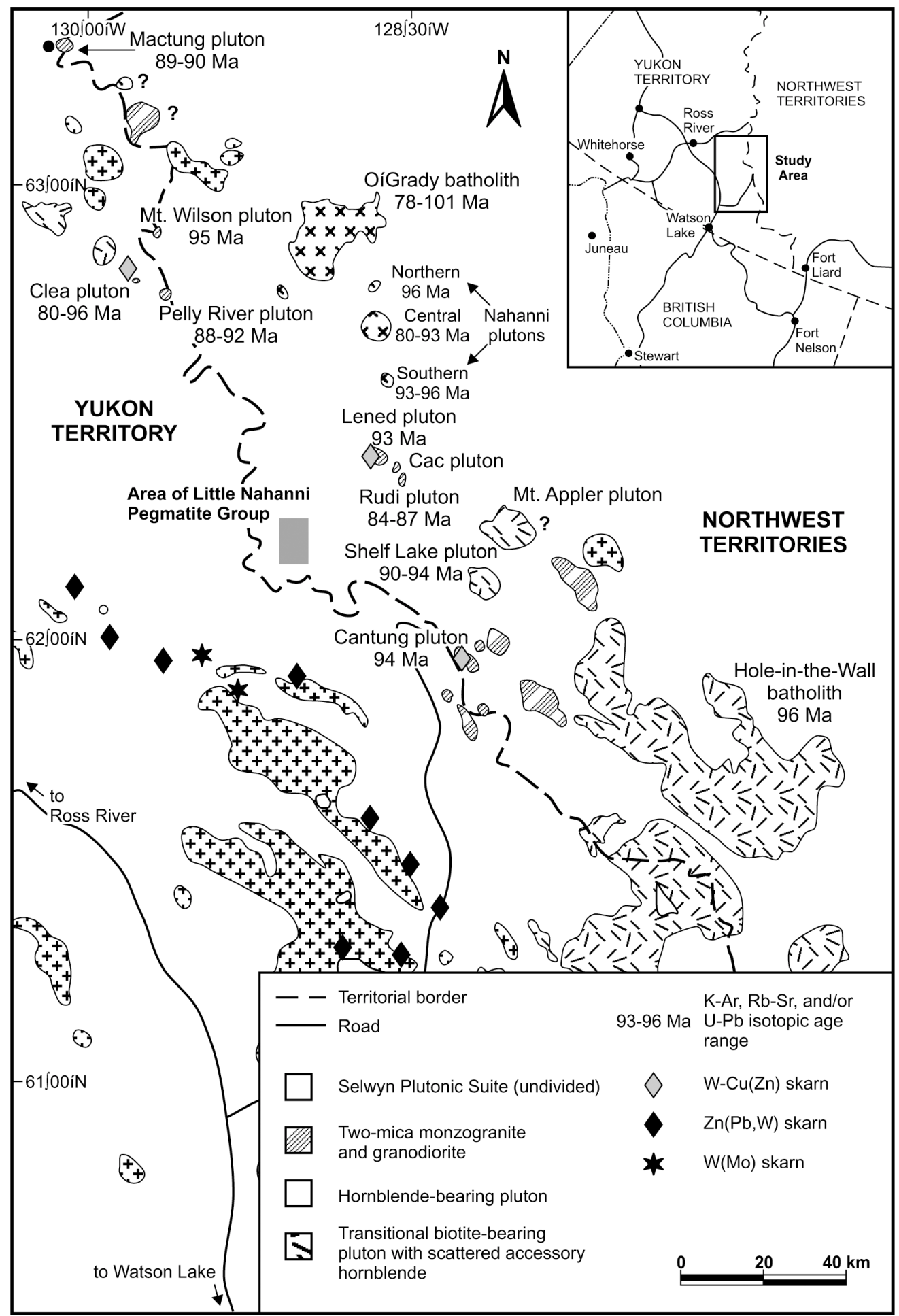

FIG. 1. Locality map, showing the Little Nahanni Pegmatite Group, the Selwyn Plutonic Suite, and skarns (adapted from Gordey \& Anderson 1993). 


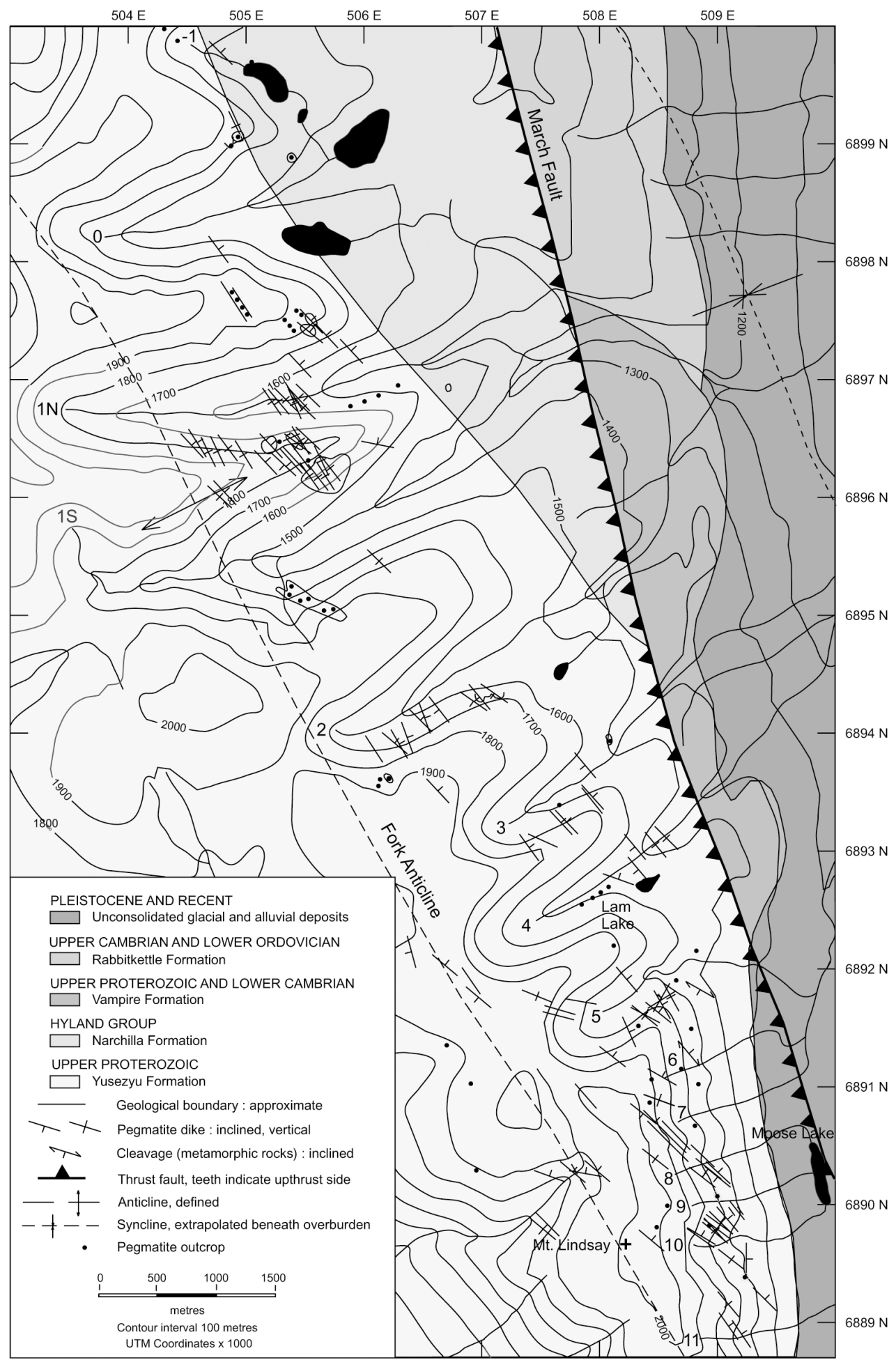

FIG. 2. Local geology of the LNPG, adapted from Gordey \& Anderson (1993). 
pending on the type of host rock. Exocontact zones in the schist commonly contain biotite, tourmaline, silvery muscovite, and quartz; much less abundant are allaniteand monazite-group minerals, zircon, and titanite. Where the dike parallels host-rock foliation, the exocontact zones have a uniform width. Where the contact is at an angle to the foliation, tourmaline- and biotite-filled fractures give an irregular width to the exocontact zone.

The Little Nahanni pegmatite dikes occur southwest of the March Fault and northeast of an erosional surface along Steel Creek (Fig. 2). Dominant structures of the range are the Fork Anticline and the Summit Syncline, which form the major features of the Selwyn Fold Belt (Gordey \& Anderson 1993). Folds trend and plunge northwest. The pegmatites are localized in the northeastern limb and axis of the Fork Anticline. They strike northwest, i.e., subparallel to the axial planes of the fold system. The pegmatite dikes are exposed in the walls of cirques, which are aligned approximately northwestsoutheast and open to the northeast, subperpendicular to the strike of the dikes (Fig. 2). Cirque floors are at $1500 \mathrm{~m}$ elevation, and walls rise to elevations near $2000 \mathrm{~m}$.

Pegmatite dikes, which commonly occur as swarms of up to 25 individuals, are tabular to lenticular, and have a high aspect-ratio; individual dikes are up to a few (maximum 10) meters wide, yet extend for several kilometers. Dike attitudes and shapes range from moderately dipping, contorted and conformable to sedimentary layering, to subvertical, tabular, undeformed and crosscutting the host strata. The pegmatites were presumably emplaced during or after the last tectonic event affecting the region.

\section{Mineralogy and Internal Structure of the Pegmatites}

Mineralogically, the pegmatites are divisible into spodumene-bearing and spodumene-free varieties, which in some places occur next to each other. One dike in cirque 10 splits into two smaller dikes, one with spodumene and the other without (Fig. 3). The two variants are similar with respect to most rock-forming minerals [K-feldspar, plagioclase, quartz, mica (muscovite to lepidolite), columbite-group minerals, cassiterite, tourmaline, beryl, lithiophilite and garnet], but differ in the abundance of mica and accessory phases. The spodumene-free pegmatites have more mica, particularly lepidolite, than the spodumene-bearing variety. Apatite and montebrasite occur primarily in the former, whereas most lithiophilite is present in the latter. Sparse galena, titanian rutile, fluorite and helvite are also found in both variants. Subsolidus phases are zeolite-group minerals,

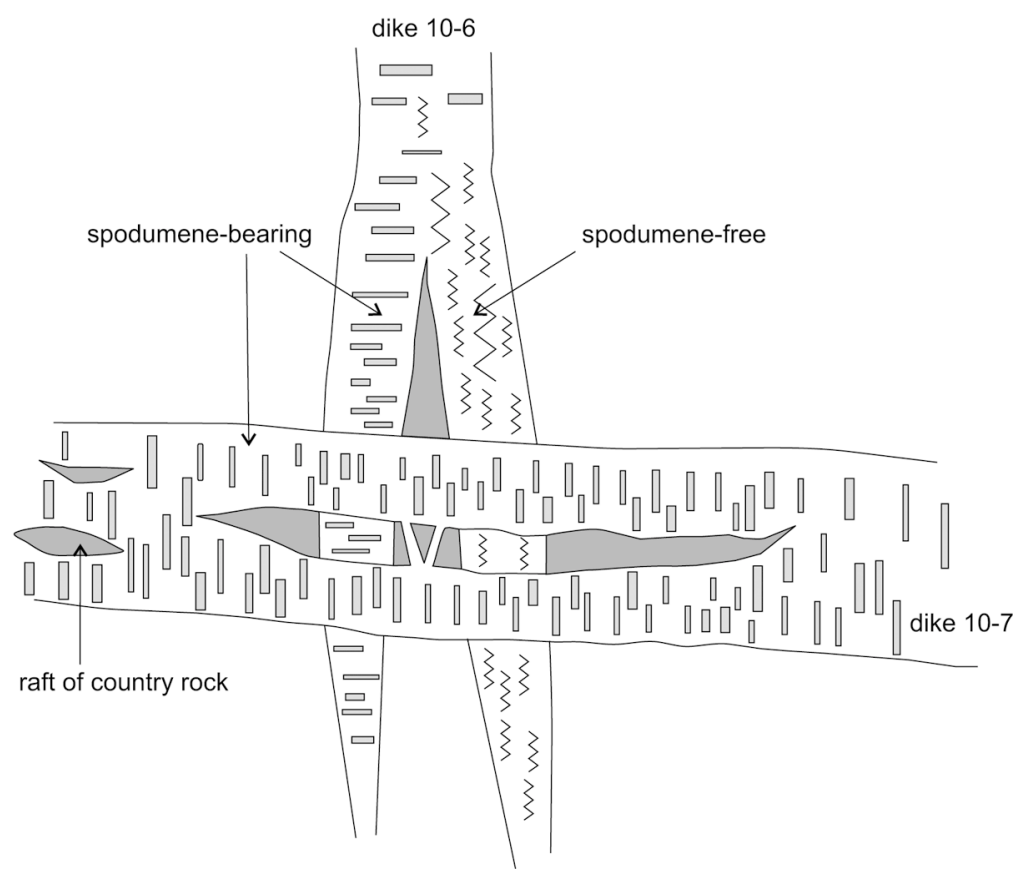

FIG. 3. Rare split and cross-cutting dikes observed in cirque 10. Dike 10-7 is approximately $1 \mathrm{~m}$ wide. 
microlite, and secondary phosphate minerals such as triploidite.

\section{Banding}

The spodumene-bearing pegmatites display a homogeneous mineral fabric and a rhythmic banding; the latter is defined by the distribution of the spodumene and quartz crystals (Fig. 4). In most cases, spodumene laths are subparallel, with their $c$ axis perpendicular to the contact. The laths overgrow and incorporate the other minerals, indicating late-stage crystallization. Homogeneous dikes show randomly distributed subparallel crystals of spodumene and other major phases such as quartz and feldspar within and across the pegmatite dikes. Aplite units are generally absent. Some dikes show an internal fabric transitional from homogeneous to rhythmic banding. Rhythmically banded dikes typically show multiple bands of spodumene laths (Fig. 4d) oriented perpendicular to the outer contact. Quartz crystals also form bands in, or near, the dike centers. The most common banding is the multiple variety, in which bands of coarse-grained spodumene + quartz + feldspar alternate with aplite. Individual bands range from a few $\mathrm{cm}$ to 30 $\mathrm{cm}$ in width. Where present, lepidolite tends to occur within the wider spodumene-bearing bands. Although areas of banding occur throughout the dikes, they rarely extend along strike for more than a few meters.
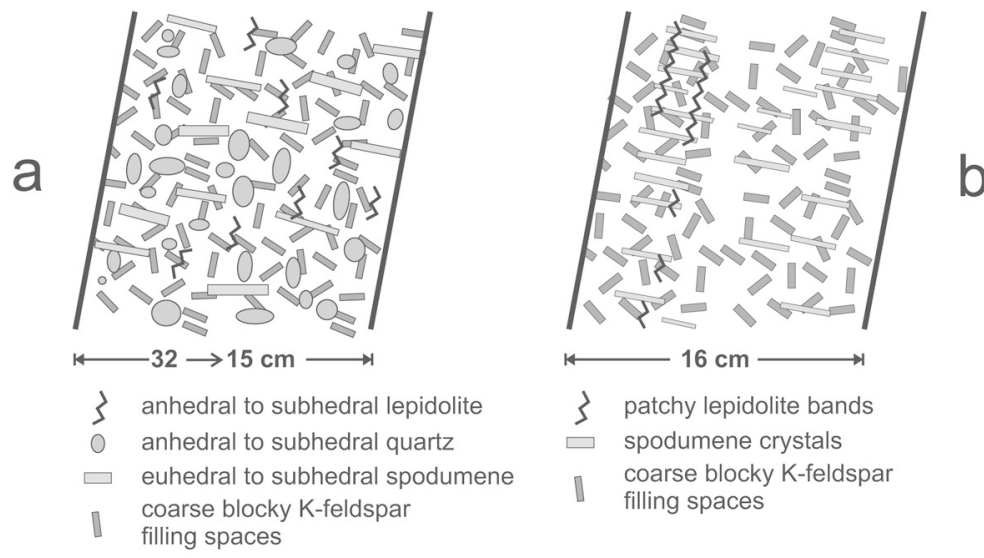

3 patchy lepidolite bands

$\square$ spodumene crystals

coarse blocky K-feldspar filling spaces
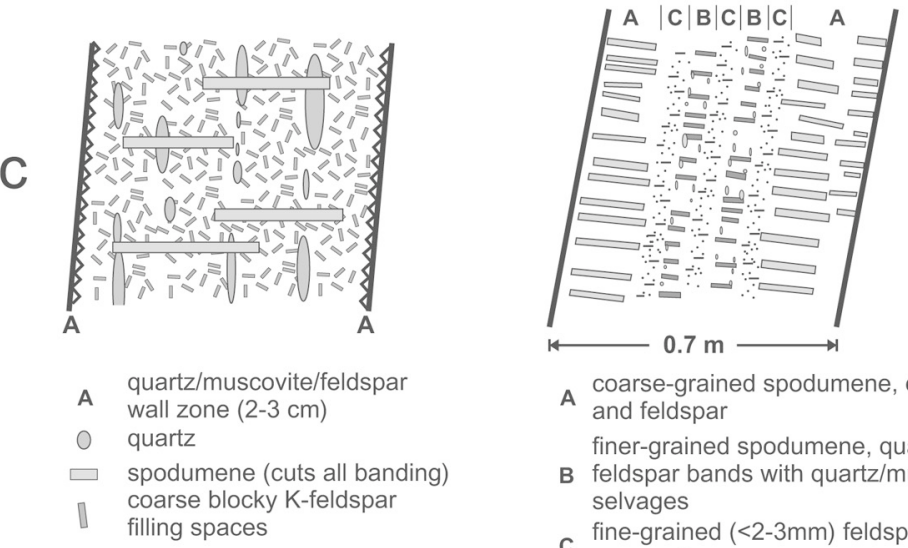
A coarse-grained spodumene, quartz and feldspar
finer-grained spodumene, quartz and
B feldspar bands with quartz/muscovite selvages
c fine-grained $(<2-3 \mathrm{~mm})$ feldspar +

FIG. 4. Internal structure of spodumene-bearing pegmatites. (a) A homogeneous dike; only the border and intermediate units are present. (b) Rhythmic banding in which the lines of spodumene are noticeable but not sharp. (c) Rhythmic banding in which the spodumene crystals are all parallel but distributed randomly across the dike; the banded appearance is due to the elongate bodies of quartz. (d) Rhythmic banding showing multiple bands of spodumene laths. 
Banding in the spodumene-free pegmatite dikes is caused by an alternation of aplite and pegmatite consisting of quartz + feldspar \pm muscovite \pm lepidolite and as variations in mineralogy of aplite layers. The pegmatite layers are coarse-grained K-feldspar and quartz with or without white to pink mica; the aplite layers are finegrained quartz and albite. A directional growth of crystals is reflected by (1) the banding in the aplite layers, parallel to dike contacts, and (2) by elongate K-feldspar crystals in the pegmatite layers, perpendicular to the dike contacts.

\section{Internal zoning}

Many dikes are poorly zoned. This discussion is based on those dikes that show discernable zoning. As the gross distribution of the most abundant minerals in both variants is similar, the zoning is described collectively. Typical zoning consists of a thin aplitic border zone, a quartz + plagioclase + muscovite wall zone, a $\mathrm{K}$-feldspar + quartz \pm spodumene intermediate zone, and a quartz \pm albite \pm spodumene core.

Border zone: Where present, the border zone varies from 1.5 to $2.5 \mathrm{~cm}$ wide, and can be aphanitic, very-fine grained (aplitic), or fine grained. The first type resembles a chilled margin, and is grey with black mineral-filled hairline strings aligned parallel to the pegmatite - host rock contact. Sporadic slightly coarsergrained quartz and mafic mineral (tourmaline or columbite-tantalite) occur within this zone. The very fine-grained border zone consists of equigranular albite ( 25 to $85 \%$ ), quartz (10 to $45 \%$ ), and mica (5 to $25 \%$ muscovite to lepidolite). Minor minerals are cassiterite and columbite-tantalite. Rare relict fragments of spodumene (probably decomposed petalite) and K-feldspar are present sporadically in some dikes. The fine-grained border zone is composed of interlocking quartz, muscovite, and plagioclase. Apatite and tourmaline comprise the accessory minerals.

Wall zone: The transition from the border to the wall unit is normally sharp where the former is aphanitic or fine-grained, and gradual where the border zone is fine grained. The wall unit consists of medium- to coarsegrained plagioclase and quartz, with less K-feldspar and spodumene. However, K-feldspar in some places is locally more abundant than plagioclase, forming a K-feldspar-quartz-rich subunit. Pegmatite bodies, particularly those that are lepidolite-bearing, emplaced in pelitic metasediments have two wall units in which the outermost subunit has higher concentrations of mica (up to $40 \%$ ) than the inner subunit.

Intermediate zone: From the wall to the intermediate zone, the minerals of the pegmatite become coarser (up to $70 \mathrm{~cm}$ across in large bodies). The first appearance of spodumene is a reliable indicator of the start of the intermediate zone in spodumene-bearing pegmatite. Generally, this unit consists of K-feldspar, plagioclase, quartz, and spodumene, and pink and white muscovite.
Minor minerals, in order of relative abundance, are phosphates, columbite-tantalite, cassiterite, tourmaline and beryl.

Core zone: A distinct core zone is rarely developed. Where present, it forms a discontinuous zone of 2 to 20 $\mathrm{cm}$ wide, and is not necessarily situated in the center of the dike, particularly in the complex banded type of dike (Fig. 4d). In the lepidolite pegmatite, the core zone normally consists of monomineralic, massive crystals of quartz or quartz + albite. In contrast, the spodumenebearing dikes have a spodumene + quartz + albite core.

Cavities: These partially crystal-filled holes within the pegmatite body are small (less than $5 \mathrm{~cm}$ in diameter) and rare. Although they are mostly associated with the intermediate and core zones, some cavities occur in the border zone of spodumene pegmatite. Two mineral assemblages have been recognized in such cavities: Kfeldspar + quartz \pm beryl \pm tourmaline \pm mica (muscovite or lepidolite) \pm apatite, and K-feldspar + quartz \pm albite \pm muscovite \pm apatite \pm helvite. Zeolite-group minerals and calcite constitute the latest phases. Cavity minerals are usually euhedral, with the exception of Kfeldspar, which is extensively corroded. In fractured or collapsed cavities, clay minerals coat the earlier phases.

\section{Analytical Methods}

A Philips XL30 scanning electron microscope equipped with a Princeton Gamma-Tech energy-dispersion X-ray spectrometer was used for preliminary examination of electron-microprobe mounts using back-scattered-electron imaging and to obtain qualitative chemical data for mineral identification. A JEOL 733 electron microprobe with Tracor-Northern 5500 and 5600 automation was used for electron-microprobe analysis (wavelength dispersion) of all minerals except some phosphates (see below). Operating conditions were $15 \mathrm{kV}, 20 \mathrm{nA}$ beam current, point focus to $30 \mu \mathrm{m}$ beam diameter. All samples were examined for chemical heterogeneities by back-scattered electron imaging; the number of points analyzed per sample depended upon the degree and scale of chemical zoning. Data for standards were collected for $50 \mathrm{~s}$ or $0.25 \%$ precision $(4 \sigma$ level), whichever was attained first; data for samples were collected for $25 \mathrm{~s}$ or $0.5 \%$ precision. An element was considered as observed only if it was significant at the $4 \sigma$ (measured) level. Data reduction was done with a conventional ZAF routine in the Tracor-Northern TASK series of programs.

Electron-probe micro-analyses of phosphate minerals other than apatite (in most instances) were done on a fully automated Cameca SX-50 microprobe, operating in wavelength-dispersion mode, with the following operating conditions: excitation voltage, $15 \mathrm{kV}$; beam current, $20 \mathrm{nA}$; beam diameter, $>10 \mu \mathrm{m}$; peak count-time, $20 \mathrm{~s}$; background count-time, $10 \mathrm{~s}$. Data reduction was done with the "PAP" $\phi(\rho Z)$ method (Pouchou \& Pichoir 1991). Information on standards, X-ray lines and crys- 
tals used may be obtained from the Depository of Unpublished Data, CISTI, National Research Council, Ottawa, Ontario K1A 0S2, Canada.

Powder X-ray-diffraction experiments were done with a Siemens D5000 diffractometer equipped with a diffracted-beam graphite monochromator, incident beam Soller slit, $2 \mathrm{~mm}$ divergence and antiscatter slits, and a $0.6 \mathrm{~mm}$ receiving slit. The normal-focus $\mathrm{Cu} \mathrm{X}$ ray tube was operated at $40 \mathrm{kV}$ and $30 \mathrm{~mA}$ ( $40 \mathrm{~mA}$ for some samples). Data were collected for 17 samples of K-feldspar, 14 of columbite-tantalite, and 13 samples of tourmaline. Samples and internal standards $\left(\mathrm{CaF}_{2}\right.$ standardized against NBS standard silicon 640a) were ground in an alumina mortar under ethanol; the mixtures were then smeared on a glass slide using a steel probe. Powder-diffraction data were collected over ranges of 10 to $70^{\circ} 2 \theta$ for columbite-tantalite, 12 to $55^{\circ}$ $2 \theta$ for K-feldspar, and 9 to $57^{\circ} 2 \theta$ for tourmaline, using scanning steps of $0.02^{\circ} 2 \theta$ for K-feldspar, $0.01^{\circ} 2 \theta$ for columbite-tantalite, and $0.04^{\circ} 2 \theta$ for tourmaline. Peak positions of each sample plus internal standard mixture were measured by Rietveld refinement using the program DBWS-9807 (Young et al. 1995). CuK $\alpha_{1}$ peaks were corrected for cell refinement by reference to the internal standard. Unit-cell dimensions were determined

\begin{tabular}{|c|c|c|c|c|}
\hline Cirque-dike & 3-3 (5) & $2-7(5)$ & $?(5)$ & $5(5)$ \\
\hline $\mathrm{P}_{2} \mathrm{O}_{5}$ (wt.\%) & 0.51 & 0.33 & 0.43 & 0.14 \\
\hline $\mathrm{SiO}_{2}$ & 63.17 & 64.62 & 62.49 & 62.50 \\
\hline $\mathrm{Al}_{2} \mathrm{O}_{3}$ & 18.34 & 18.57 & 18.82 & 18.53 \\
\hline $\mathrm{Fe}_{2} \mathrm{O}_{3}$ & 0.00 & 0.00 & 0.00 & 0.00 \\
\hline $\mathrm{CaO}$ & 0.00 & 0.00 & 0.00 & 0.00 \\
\hline $\mathrm{MnO}$ & 0.00 & 0.00 & 0.00 & 0.00 \\
\hline $\mathrm{SrO}$ & 0.08 & 0.08 & 0.08 & 0.09 \\
\hline $\mathrm{BaO}$ & 0.00 & 0.00 & 0.00 & 0.01 \\
\hline $\mathrm{Na}_{2} \mathrm{O}$ & 0.89 & 0.69 & 1.10 & 0.29 \\
\hline $\mathrm{K}_{2} \mathrm{O}$ & 14.57 & 15.25 & 15.03 & 16.32 \\
\hline $\mathrm{Rb}_{2} \mathrm{O}$ & 1.23 & 0.59 & 0.78 & 0.61 \\
\hline $\mathrm{Cs}_{2} \mathrm{O}$ & 0.16 & 0.00 & 0.01 & 0.01 \\
\hline Total & 98.95 & 100.13 & 98.72 & 98.50 \\
\hline $\mathrm{P}^{5+}(a p f u)$ & 0.020 & 0.013 & 0.017 & 0.006 \\
\hline $\mathrm{Si}^{4+}$ & 2.964 & 2.981 & 2.939 & 2.959 \\
\hline $\mathrm{Al}^{3+}$ & 1.014 & 1.010 & 1.043 & 1.034 \\
\hline $\mathrm{Fe}^{3+}$ & 0.000 & 0.000 & 0.000 & 0.000 \\
\hline $\mathrm{Ca}^{2+}$ & 0.000 & 0.000 & 0.000 & 0.000 \\
\hline $\mathrm{Mn}^{2+}$ & 0.000 & 0.000 & 0.000 & 0.000 \\
\hline $\mathrm{Sr}^{2+}$ & 0.002 & 0.002 & 0.002 & 0.002 \\
\hline $\mathrm{Ba}^{2+}$ & 0.000 & 0.000 & 0.000 & 0.000 \\
\hline $\mathrm{Na}^{+}$ & 0.081 & 0.062 & 0.100 & 0.027 \\
\hline $\mathrm{K}^{+}$ & 0.872 & 0.898 & 0.902 & 0.986 \\
\hline $\mathrm{Rb}^{+}$ & 0.037 & 0.017 & 0.024 & 0.019 \\
\hline $\mathrm{Cs}^{+}$ & 0.003 & 0.000 & 0.000 & 0.000 \\
\hline Or (mol. \%) & 92 & 94 & 90 & 97 \\
\hline$A b$ & 8 & 6 & 10 & 3 \\
\hline
\end{tabular}

Note: The following standards were used: apatite $(P K \alpha)$ sanidine $(\mathrm{Si} K \alpha, \mathrm{AIK} \alpha, \mathrm{K} K \alpha)$, almandine $(\mathrm{Fe} K \alpha)$, diopside $(\mathrm{CaK} \alpha)$, tephroite $(\mathrm{MnK} \alpha)$, celestite $(\mathrm{SrK} \alpha)$, sanbornite $(\mathrm{BaK} \alpha)$, albite $(\mathrm{NaK} \alpha)$, microcline $(\mathrm{Rb} K \alpha)$, and pollucite (CsKa). Compositions were recalculated on the basis of 80 apfu. The number of point compositions used in averaging is shown in brackets. Maximum values are shown in bold. from the corrected X-ray powder-diffraction data using the program UnitCell (Holland \& Redfern 1997).

\section{Mineralogy and Mineral Chemistry}

\section{Plagioclase}

Albite is the dominant feldspar in the LNPG, occurring in three major textural varieties: white to creamcolored crystals with "cleavelandite" habit, white to slightly grayish saccharoidal material, and brownish grey, fine- to medium-grained crystals. "Cleavelandite", ranging from 0.5 to $5 \mathrm{~cm}$ in grain size, is the major constituent in coarse-grained, particularly spodumene-free dikes. Here the albite plates are intergrown with quartz, K-feldspar and, in some places, muscovite or lepidolite. This variety is also found with calcite occurring as fracture-fillings. Saccharoidal albite $(\sim 0.1$ to $0.5 \mathrm{~mm})$ occurs with equally fine-grained lepidolite and quartz, mostly in the border and wall zones of the pegmatite body. Fine- to medium-grained ( 1 to $5 \mathrm{~mm}$ ) albite is ubiquitous across the dikes, occurring with equal amounts of quartz and muscovite in the aplitic layers and pods of the pegmatites. Subsolidus albite partially or completely replaces blocky K-feldspar in the intermediate zone. The albite is almost pure $\mathrm{NaAlSi}_{3} \mathrm{O}_{8}$; the maximum $\mathrm{Ca}$ content is 0.02 atoms per formula unit (apfu), corresponding to $\mathrm{An}_{2}$. Analyzed grains of albite contain $\mathrm{Sr}(0.03$ to $0.07 \mathrm{wt} . \% \mathrm{SrO})$ and $\mathrm{P}(0.04$ to 0.68 wt. $\% \mathrm{P}_{2} \mathrm{O}_{5}$ ).

\section{$K$-feldspar}

K-feldspar ranges from white, to gray, to mottled brown, and occurs as blocky and elongate crystals. Blocky K-feldspar crystals from 2 to $70 \mathrm{~cm}$ long are common in the intermediate zone of the pegmatite, where they are intergrown with other minerals. These crystals also occur in the core of the pegmatites, where they surround quartz grains. Elongate anhedral K-feldspar forms, on average, 1-cm-wide stringer-like crystals aligned parallel to each other, and generally alternating with rod-shaped spodumene laths. In many dikes, these two types of mineral are oriented perpendicular to the contact between the pegmatite and the wall rock. Anhedral K-feldspar is fine-grained, and normally occurs in the wall zone of the pegmatite bodies. Euhedral cryptoperthite crystals are restricted to calcitefilled fractures and pockets, which are relatively rare features in the Little Nahanni pegmatites.

Subsolidus alteration in the K-feldspar varies from rims and patches of albite to extensive replacements by albite \pm white mica. In some pockets, the K-feldspar is etched completely, and has been transformed into boxwork-like frameworks of albite and zeolite.

Point analyses of the K-feldspar reveal a range from $\mathrm{Or}_{90} \mathrm{Ab}_{10} \mathrm{An}_{0}$ to $\mathrm{Or}_{97} \mathrm{Ab}_{3} \mathrm{An}_{0}$ (Table 1); the highest $\mathrm{Ab}$ content corresponds to the maximum $\mathrm{Na}_{2} \mathrm{O}$ value of 
1.10 wt. $\%$. The high Or and low $\mathrm{Na}$ and $\mathrm{Ca}$ contents are an indication of subsolidus equilibration. Rubidium is the second most abundant substituting element, ranging from 0.39 to 1.23 wt.\% $\mathrm{Rb}_{2} \mathrm{O}$. Phosphorus content is rather erratic (trace to $0.51 \mathrm{wt} . \% \mathrm{P}_{2} \mathrm{O}_{5}$ ). The concentrations of $\mathrm{Ca}, \mathrm{Mn}, \mathrm{Fe}, \mathrm{Sr}, \mathrm{Cs}$, and $\mathrm{Ba}$ are nil or negligible.

Unit-cell dimensions were refined for $17 \mathrm{~K}$-feldspar samples, mostly from pegmatites in the northern part of the study area (Table 2). Plots of $b$ versus $c$ and $\gamma^{*}$ versus $\alpha^{*}$ (Fig. 5) show that the structural state varies from intermediate microcline to almost completely ordered low microcline, implying a relatively large spread in the $\mathrm{Al}-\mathrm{Si}$ order. This spread suggests rapid cooling of the felsic melt, which in turns implies a high level of emplacement for the pegmatite. All points, within the mar-

TABLE 2. UNIT-CELL DIMENSIONS OF K-FELDSPAR SAMPLES FROM THE LITTLE NAHANNI PEGMATITE GROUP

\begin{tabular}{lccccccc}
\hline Cirque-dike & $a(\AA)$ & $b(\AA)$ & $c(\AA)$ & $\alpha\left(^{\circ}\right)$ & $\beta\left(^{\circ}\right)$ & $\gamma\left({ }^{\circ}\right)$ & $V\left(\AA^{3}\right)$ \\
\hline $4-1$ & $8.590(2)$ & $12.973(2)$ & $7.207(1)$ & $90.20(1)$ & $115.93(2)$ & $89.29(1)$ & $722.4(3)$ \\
3 & $8.602(1)$ & $12.979(2)$ & $7.208(1)$ & $90.15(1)$ & $116.00(1)$ & $89.43(1)$ & $723.3(2)$ \\
$5 \mathrm{~W}$ & $8.588(2)$ & $12.979(2)$ & $7.204(1)$ & $90.07(1)$ & $115.94(1)$ & $89.65(2)$ & $722.1(2)$ \\
$0-1$ & $8.595(1)$ & $12.980(1)$ & $7.205(1)$ & $90.10(1)$ & $116.06(1)$ & $89.58(1)$ & $722.1(1)$ \\
$?$ & $8.596(1)$ & $12.987(1)$ & $7.204(1)$ & $90.06(1)$ & $116.05(0)$ & $89.76(1)$ & $722.5(1)$ \\
$2-7$ & $8.597(1)$ & $12.981(1)$ & $7.208(1)$ & $90.05(1)$ & $116.01(1)$ & $89.66(2)$ & $722.9(2)$ \\
$4-1 \mathrm{~B}$ & $8.590(1)$ & $12.992(1)$ & $7.201(1)$ & $90.04(1)$ & $116.07(0)$ & $89.84(2)$ & $721.9(1)$ \\
$4-1 \mathrm{C}$ & $8.595(2)$ & $12.977(2)$ & $7.208(1)$ & $90.30(1)$ & $116.05(1)$ & $88.91(2)$ & $722.2(2)$ \\
$9^{\wedge} 10-1$ & $8.606(2)$ & $12.989(3)$ & $7.206(2)$ & $90.08(2)$ & $116.02(1)$ & $89.72(2)$ & $723.9(3)$ \\
$9^{\wedge} 10-3$ & $8.609(1)$ & $12.978(1)$ & $7.208(1)$ & $90.18(1)$ & $116.00(1)$ & $89.34(1)$ & $723.8(2)$ \\
5 & $8.601(2)$ & $12.968(2)$ & $7.211(1)$ & $90.20(2)$ & $115.93(1)$ & $89.19(2)$ & $723.3(2)$ \\
$1 \mathrm{~N}-4$ & $8.593(1)$ & $12.967(2)$ & $7.215(1)$ & $90.37(1)$ & $115.99(1)$ & $88.58(1)$ & $722.4(2)$ \\
$1 \mathrm{~N}-16$ & $8.593(1)$ & $12.979(2)$ & $7.205(1)$ & $90.08(1)$ & $115.97(1)$ & $89.65(2)$ & $722.4(2)$ \\
$1 \mathrm{~N}-10$ & $8.598(1)$ & $12.984(1)$ & $7.205(0)$ & $90.02(1)$ & $116.07(1)$ & $89.82(2)$ & $722.5(1)$ \\
$1 \mathrm{~N}-19$ & $8.586(1)$ & $12.982(1)$ & $7.206(1)$ & $90.11(1)$ & $115.98(1)$ & $89.62(1)$ & $722.0(1)$ \\
$1 \mathrm{~N}-18$ & $8.598(1)$ & $12.986(2)$ & $7.202(1)$ & $90.08(1)$ & $116.04(1)$ & $89.70(2)$ & $722.5(2)$ \\
$3-3$ & $8.595(1)$ & $12.981(2)$ & $7.204(1)$ & $90.08(1)$ & $115.96(1)$ & $89.64(2)$ & $722.6(2)$
\end{tabular}

gin of error, fall inside the $b-c$ quadrilateral, indicating that the $b$ and $c$ cell edges remain close to the ideal values.

\section{Spodumene}

Colorless to light pink primary spodumene occurs as elongate or bladed and stubby crystals exclusively in the intermediate and core zones. Rare, anhedral xenocrysts of spodumene are present in the border or wall zones of some pegmatites. The primary spodumene constitutes up to $20 \%$ by volume of the host pegmatite, and the average content is 5 to $7 \%$. The elongate crystals, up to $0.5 \mathrm{~m}$ but generally between 10 and $15 \mathrm{~cm}$ long, are parallel to and alternate with K-feldspar rods, and these two minerals are perpendicular to the country-rock contact. The stubby crystals, 2 to $4 \mathrm{~cm}$ long, are randomly oriented, and do not normally occur in the same dikes with the elongate crystals. Commonly, the mineral is intergrown with blocky K-feldspar, or massive albite \pm quartz \pm mica (lepidolite, or less commonly, muscovite). Rarely, intergrowths of spodumene and quartz appear to have replaced petalite, and some of these display a symplectitic texture (SQUI).

Many spodumene crystals are altered. Strongly altered spodumene leaves relict fragments within a pseudomorph of a secondary mineral (after spodumene) and albite. Fragments range from vibrant pink to dark purple, to green and black, and lack cleavage. Powder $\mathrm{X}$-ray diffraction analyses of the replacement materials indicate that they are mixtures of illite-montmorillonite, kaolinite, mica (white mica and lepidolite), and albite.
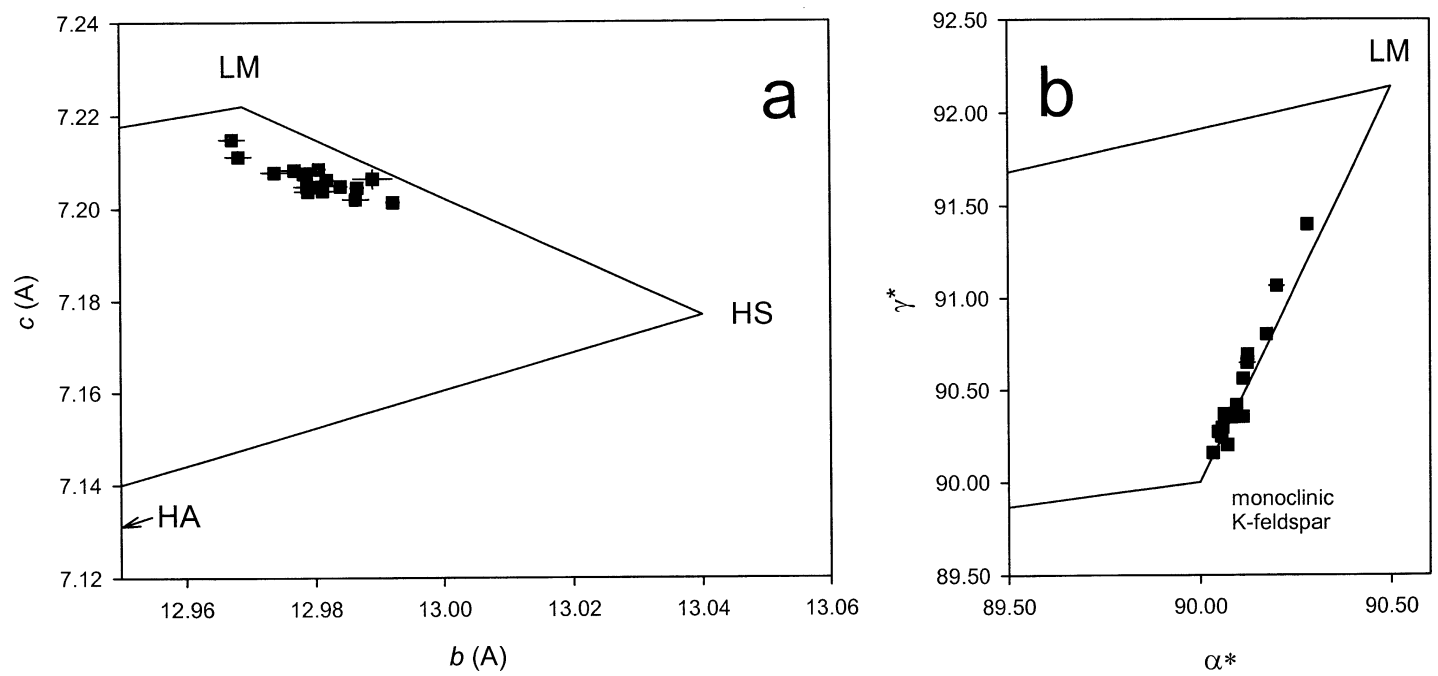

FIG. 5. (a) A portion of the $b-c$ quadrilateral showing the distribution of data points. Symbols: LM low microcline, HS high sanidine, HA high albite. (b) A portion of the $\alpha^{*}-\gamma^{*}$ plot showing the location of data points with respect to the LM corner. 
The major-element composition of spodumene is generally homogeneous and is very close to $\mathrm{LiAlSi}_{2} \mathrm{O}_{6}$; notable maximum values for extraneous elements such as $\mathrm{Na}$ and $\mathrm{Fe}$ are 0.01 and $0.03 a p f u$, respectively. An exception to this is provided by a crystal from dike $1 \mathrm{~N}-$ 30A, which shows a decreasing trend of Fe content from core to rim. It is interesting to note that spodumene with lower Fe/Mn values shows a deeper pink hue, and that green spodumene is found to be Mn-free and Fe-rich.

\section{The micas}

Micas from the LNPG are colorless to silver to deep purple. The colorless to silver variety occurs in the wall and aplitic zones of many dikes, where it forms masses of medium- to coarse-grained crystals, books or "scaly" aggregates, generally associated with spodumene, quartz, and feldspar. In some cases, coarse-grained purple mica forms cone-shaped aggregates with a botryoidal "ball-peen" habit. The euhedral habit and texture, along with the lack of compositional zoning (see below), suggest that the coarse-grained mica, lepidolite in particular, is magmatic. Fine-grained crystals of colorless to silver mica occur in the border zone of some dikes, associated with similarly fine-grained quartz and albite.

Back-scattered-electron images and electron-microprobe analyses show that individual micas are compositionally homogeneous (Table 3 ). The Li values were calculated to yield a 1:1 atom per formula unit correlation between the F and Li contents (Levillain 1980). Fluorine concentrations range from below detection level to $6.66 \mathrm{wt} . \%$; the latter corresponds to $5.24 \mathrm{wt} . \%$ $\mathrm{Li}_{2} \mathrm{O}(2.797 \mathrm{Li} a p f u)$. Other concentration ranges are as follows: $\mathrm{Na}_{2} \mathrm{O}, 0.16$ to $0.80, \mathrm{Al}_{2} \mathrm{O}_{3} 24.44$ to $39.54, \mathrm{SiO}_{2}$ 41.26 to 52.17 , and $\mathrm{K}_{2} \mathrm{O} 10.14$ to 11.25 wt.\%. $\mathrm{MgO}$, $\mathrm{MnO}$, and $\mathrm{FeO}$ contents range from below detection limit to $0.20,1.04$, and $0.91 \mathrm{wt} \%$, respectively.

The compositions are plotted on a "Foster" diagram (Foster 1960) in Figure 6. The diagram shows that the mica ranges from true muscovite to trilithionite. Surprisingly few compositions plot in the lithian muscovite field, between about 10 and $25 \% \mathrm{Li}$.

Rubidium, Cs, and Sr contents range from below detection limit to 17974, 3936, and $611 \mathrm{ppm}$, respectively. Moderate to strong correlations are shown by K/ $\mathrm{Rb}$ versus $\mathrm{Rb}, \mathrm{K} / \mathrm{Cs}$ versus $\mathrm{Cs}$, and $\mathrm{K} / \mathrm{Sr}$ versus $\mathrm{Sr}$ (Fig. 7). The $\mathrm{Rb}$ contents show positive correlations with $\mathrm{Li} / \mathrm{F}, \mathrm{Si}$, and $\mathrm{Mn}$, and negative correlations with $\mathrm{Na}$ and $\mathrm{Al}$. Potassium and $\mathrm{Fe}$ contents seem to be independent of $\mathrm{Rb}$ content. The mica from the northernmost cirques is slightly more enriched in Fe relative to that from the southern part of the group.

\section{Columbite-group minerals}

Minerals of the columbite group (CT) occur as disseminated crystals, largely in the aplite unit, but also in

$\mathrm{Li}$

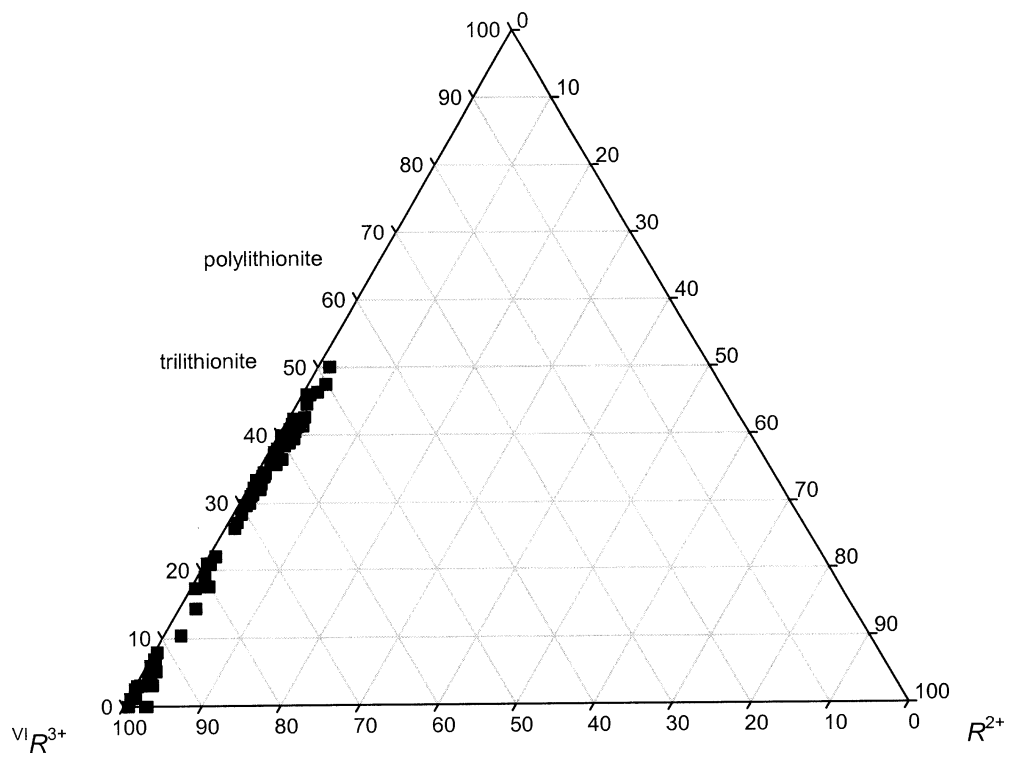

FIG. 6. "Foster" diagram of mica compositions (after Foster 1960). This and all succeeding compositional diagrams are based on averaged compositions of individual crystals. 
the wall and intermediate zones of the host pegmatite. Subhedral to euhedral, blocky to tabular crystals (less than $1 \mathrm{~mm}$ to $5 \mathrm{~cm}$ long) generally are intergrown with albite (rarely with tourmaline), and interstitial to the Kfeldspar and quartz. Wodginite and columbite-group minerals are intergrown in some samples. Tantalian rutile and uraninite occur as rare inclusions. Many CT crystals, particularly the larger ones, show strong oscillatory or patchy zoning. Subsolidus alteration of some CT grains is indicated by overgrowths and replacement along the rims.

The chemical composition of CT minerals from the LNPG is dominated by $\mathrm{Mn}$ over $\mathrm{Fe}$ and $\mathrm{Nb}$ over $\mathrm{Ta}$ (Table 4), and the majority plot within the manganocolumbite quadrant (Fig. 8); the values of $\mathrm{Mn} /(\mathrm{Mn}+$ $\mathrm{Fe}$ ) range from 0.416 to 0.998 , and of $\mathrm{Ta} /(\mathrm{Ta}+\mathrm{Nb})$, from 0.085 to 0.658 . $\mathrm{Ti}, \mathrm{Zr}$, and $\mathrm{Sn}$ are common trace elements, with a maximum concentration of 0.523 , 0.054 , and $0.127 a p f u$, respectively. Sc and W contents are generally below the detection limit, and the maximum concentration is approximately $0.05 \mathrm{apfu}$ for both elements. The sum of the cations is between 11.93 and 12.09 apfu, implying that $\mathrm{Fe}^{3+}$ is absent or insignificant.

The wide variations in $\mathrm{Mn}, \mathrm{Fe}, \mathrm{Nb}$ and $\mathrm{Ta}$ contents are attributed to the homovalent exchanges $\mathrm{Ta} \leftrightarrow \mathrm{Nb}$ and $\mathrm{Mn} \leftrightarrow \mathrm{Fe}$. This is supported by the linear relationships between $\mathrm{Ta}$ and $\mathrm{Nb}$, and between $\mathrm{Mn}$ and $\mathrm{Fe}$. The levels of Ti and Sn decrease with increasing $\mathrm{Mn} /(\mathrm{Mn}+$ $\mathrm{Fe}$ ), whereas $\mathrm{Zr}$ shows a positive correlation at high values of $\mathrm{Mn} /(\mathrm{Mn}+\mathrm{Fe}$ ) (Fig. 9). No correlations among or between $\mathrm{Ti}, \mathrm{Sn}$, and $\mathrm{Zr}$, and $\mathrm{Ta} /(\mathrm{Ta}+\mathrm{Nb})$ were observed.

TABLE 3. SELECTED AVERAGE COMPOSITIONS OF MICA FROM THE LITTLE NAHANNI PEGMATITE GROUP

\begin{tabular}{|c|c|c|c|c|c|c|c|c|c|c|c|}
\hline $\begin{array}{l}\text { Cirque- } \\
\text { dike }\end{array}$ & 4-? (2) & $1 \mathrm{~N}-?(2)$ & $2-3(8)$ & $5-2(2)$ & $2-7(9)$ & $5-6(2)$ & 3-? (2) & $1 \mathrm{~S}(2)$ & $3-1(2)$ & $1 \mathrm{~N}-30(2)$ & $3-9(2)$ \\
\hline $\mathrm{SiO}_{2}$ (wt.\%) & 52.17 & 41.65 & 45.25 & 49.31 & 45.37 & 45.05 & 51.89 & 44.57 & 45.57 & 46.49 & 49.12 \\
\hline $\mathrm{Al}_{2} \mathrm{O}_{3}$ & 26.43 & 39.54 & 36.74 & 28.64 & 36.31 & 38.03 & 24.44 & 37.63 & 28.62 & 31.01 & 29.17 \\
\hline $\mathrm{MgO}$ & 0.00 & 0.03 & 0.20 & 0.00 & 0.04 & 0.02 & 0.00 & 0.00 & 0.00 & 0.00 & 0.00 \\
\hline $\mathrm{MnO}$ & 0.46 & 0.00 & 0.00 & 1.04 & 0.04 & 0.17 & 0.63 & 0.16 & 0.42 & 0.67 & 0.91 \\
\hline $\mathrm{FeO}$ & 0.00 & 0.04 & 0.70 & 0.07 & 0.91 & 0.03 & 0.09 & 0.45 & 0.00 & 0.00 & 0.10 \\
\hline $\mathrm{SrO}$ & 0.02 & 0.00 & 0.06 & 0.07 & 0.06 & 0.08 & 0.00 & 0.07 & 0.00 & 0.00 & 0.06 \\
\hline $\mathrm{Li}_{2} \mathrm{O}$ & 4.74 & 0.23 & 0.00 & 4.14 & 0.00 & 0.55 & 5.24 & 0.40 & 3.85 & 2.89 & 3.88 \\
\hline $\mathrm{Na}_{2} \mathrm{O}$ & 0.21 & 0.44 & 0.53 & 0.16 & 0.45 & 0.50 & 0.16 & 0.80 & 0.23 & 0.28 & 0.21 \\
\hline $\mathrm{K}_{2} \mathrm{O}$ & 10.89 & 10.91 & 10.62 & 11.08 & 10.60 & 10.74 & 10.86 & 10.14 & 10.97 & 10.64 & 10.70 \\
\hline $\mathrm{Rb}_{2} \mathrm{O}$ & 1.74 & 0.60 & 0.46 & 0.96 & 0.58 & 0.16 & 1.55 & 0.53 & 1.27 & 1.97 & 1.34 \\
\hline $\mathrm{Cs}_{2} \mathrm{O}$ & 0.13 & 0.02 & 0.01 & 0.05 & 0.06 & 0.00 & 0.19 & 0.00 & 0.10 & 0.13 & 0.42 \\
\hline $\mathrm{H}_{2} \mathrm{O}^{*}$ & 1.74 & 4.26 & 4.46 & 2.03 & 4.45 & 4.19 & 1.36 & 4.24 & 1.97 & 2.67 & 2.18 \\
\hline $\mathrm{F}$ & 6.03 & 0.29 & 0.00 & 5.27 & 0.00 & 0.70 & 6.66 & 0.51 & 4.90 & 3.67 & 4.94 \\
\hline $\mathrm{O}=\mathrm{F}$ & -2.54 & -0.12 & 0.00 & -2.22 & 0.00 & -0.29 & -2.80 & -0.21 & -2.06 & -1.55 & -2.08 \\
\hline Total & 102.02 & 97.89 & 99.03 & 100.60 & 98.87 & 99.93 & 100.27 & 99.29 & 95.84 & 98.88 & 100.95 \\
\hline $\mathrm{Si}^{4+}(a p f u)$ & 6.802 & 5.680 & 6.077 & 6.531 & 6.115 & 5.968 & 6.887 & 5.963 & 6.366 & 6.317 & 6.508 \\
\hline $\mathrm{Al}^{3+}$ & 4.061 & 6.355 & 5.815 & 4.471 & 5.768 & 5.938 & 3.823 & 5.934 & 4.712 & 4.966 & 4.555 \\
\hline $\mathrm{Mg}^{2+}$ & 0.000 & 0.006 & 0.040 & 0.000 & 0.008 & 0.004 & 0.000 & 0.000 & 0.000 & 0.000 & 0.000 \\
\hline $\mathrm{Mn}^{2+}$ & 0.051 & 0.000 & 0.000 & 0.117 & 0.005 & 0.019 & 0.071 & 0.018 & 0.050 & 0.077 & 0.102 \\
\hline $\mathrm{Fe}^{2+}$ & 0.000 & 0.005 & 0.079 & 0.008 & 0.103 & 0.003 & 0.010 & 0.050 & 0.000 & 0.000 & 0.011 \\
\hline $\mathrm{Sr}^{2+}$ & 0.002 & 0.000 & 0.005 & 0.005 & 0.005 & 0.006 & 0.000 & 0.005 & 0.000 & 0.000 & 0.005 \\
\hline $\mathrm{Li}^{+}$ & 2.485 & 0.126 & 0.000 & 2.205 & 0.000 & 0.293 & 2.797 & 0.215 & 2.163 & 1.579 & 2.067 \\
\hline $\mathrm{Na}^{+}$ & 0.053 & 0.116 & 0.138 & 0.041 & 0.118 & 0.128 & 0.041 & 0.208 & 0.062 & 0.074 & 0.054 \\
\hline $\mathrm{K}^{+}$ & 1.811 & 1.898 & 1.820 & 1.872 & 1.823 & 1.815 & 1.839 & 1.731 & 1.955 & 1.845 & 1.809 \\
\hline $\mathrm{Rb}^{+}$ & 0.146 & 0.053 & 0.040 & 0.082 & 0.050 & 0.014 & 0.132 & 0.046 & 0.114 & 0.172 & 0.114 \\
\hline $\mathrm{Cs}^{+}$ & 0.007 & 0.001 & 0.001 & 0.003 & 0.003 & 0.000 & 0.011 & 0.000 & 0.060 & 0.008 & 0.024 \\
\hline $\mathrm{H}^{+}$ & 1.513 & 3.875 & 4.000 & 1.792 & 4.000 & 3.707 & 1.204 & 3.784 & 1.835 & 2.423 & 1.930 \\
\hline $\mathrm{F}^{-}$ & 2.487 & 0.125 & 0.000 & 2.208 & 0.000 & 0.293 & 2.796 & 0.216 & 2.165 & 1.577 & 2.070 \\
\hline $\mathrm{Rb}(\mathrm{ppm})$ & 15896 & 5453 & 4204 & 8735 & 5330 & 1464 & 14143 & 4850 & 11603 & 17974 & 235 \\
\hline $\mathrm{Sr}$ & 151 & 0 & 488 & 523 & 474 & 611 & 0 & 569 & 0 & 0 & 522 \\
\hline Cs & 1205 & 267 & 46 & 461 & 596 & 0 & 1797 & 55 & 926 & 1206 & 3936 \\
\hline
\end{tabular}

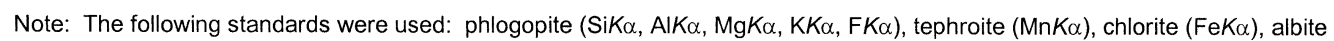
$(\mathrm{NaK} \alpha)$, microcline $(\mathrm{Rb} K \alpha)$, celestite $(\mathrm{Sr} K \alpha)$, and pollucite $(\mathrm{Cs} K \alpha)$. Compositions were recalculated on the basis of $\mathrm{Li}: \mathrm{F}=1: 1$ apfu and $24(\mathrm{O}+\mathrm{OH}+\mathrm{F})$. The number of point compositions used in averaging is shown in brackets. Maximum values are shown in bold. ${ }^{\star}$ Determined by stoichiometry 
(a)

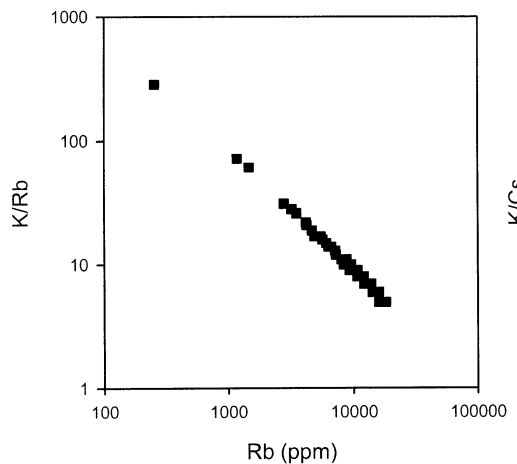

(c)

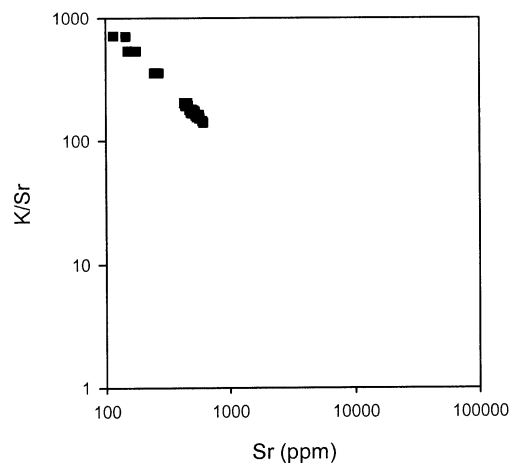

(b)

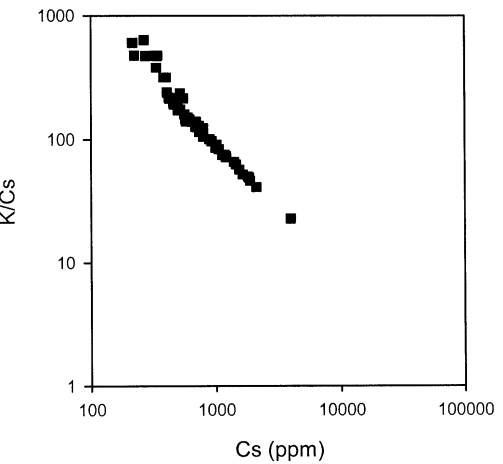

Fig. 7. Mica compositions. (a) $\mathrm{K} / \mathrm{Rb}$ versus $\mathrm{Rb}$ (ppm). (b) $\mathrm{K} /$ Cs versus $\mathrm{Cs}(\mathrm{ppm})$. (c) $\mathrm{K} / \mathrm{Sr}$ versus $\mathrm{Sr}(\mathrm{ppm})$.
Compositional variations within single grains are complex, as shown in Figure 10. In most crystals, the $\mathrm{Mn} /(\mathrm{Mn}+\mathrm{Fe})$ values change little, or show an initial increase or decrease then remain constant. However, in some patchily zoned grains, this ratio changes greatly, generally showing a positive trend from core to rim. Overgrown or replaced parts of CT grains generally show higher values of $\mathrm{Ta} /(\mathrm{Ta}+\mathrm{Nb})$ than sections containing primary compositions.

Unit-cell dimensions of the columbite-group minerals show limited structural variation from moderate (71\% order) to strongly ordered (94\% order; Table 5). In general, the degree of cation order increases with decreasing concentration of impurity elements (Fig. 11).

\section{Cassiterite}

Cassiterite occurs as disseminated subhedral grains in quartz- and lepidolite-rich parts (locally $10 \%$ vol.) of the wall and intermediate zones, as bands between two texturally distinct zones of the pegmatite body (Fig. 12) and along microfractures, and as sharp, lustrous, wedgeshaped crystals in calcite-filled miarolitic cavities. It ranges in size from microscopic to $1.5 \mathrm{~cm}$ wide, is com-

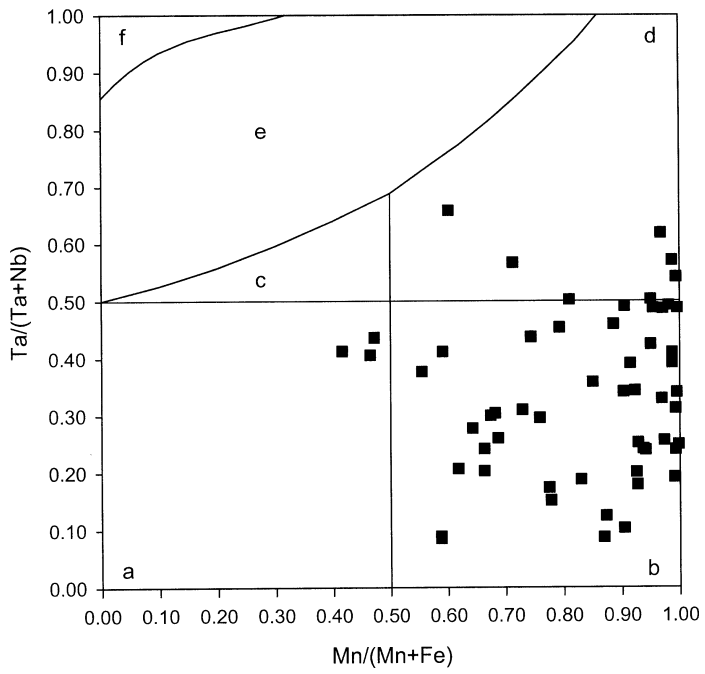

FIG. 8. $\mathrm{Ta} /(\mathrm{Ta}+\mathrm{Nb})$ versus $\mathrm{Mn} /(\mathrm{Mn}+\mathrm{Fe})$ for the columbitetantalite minerals: (a) ferrocolumbite, (b) manganocolumbite, (c) ferrotantalite, (d) manganotantalite, (e) two phases, (f) tapiolite. 
TABLE 4. SELECTED AVERAGE COMPOSITIONS OF COLUMBITE-TANTALITE FROM THE LITTLE NAHANNI PEGMATITE GROUP

\begin{tabular}{lrrrrrrrr}
\hline $\begin{array}{l}\text { Cirque- } \\
\text { dike }\end{array}$ & $5-8(1)$ & $1 \mathrm{~N}-1(2)$ & $3-1(1)$ & $2-1(3)$ & $4-1(6)$ & $4 \mathrm{~W}(3)$ & $1 \mathrm{~N}-1(8)$ & $4(7)$ \\
\hline $\mathrm{WO}_{3}(\mathrm{wt} . \%)$ & 1.02 & 0.40 & 0.00 & 0.13 & 0.00 & 0.00 & 0.00 & 0.00 \\
$\mathrm{Nb}_{2} \mathrm{O}_{5}$ & 63.46 & $\mathbf{6 7 . 8 6}$ & 19.81 & 35.79 & 45.75 & 22.62 & 26.17 & 52.32 \\
$\mathrm{Ta}_{2} \mathrm{O}_{5}$ & 15.02 & 10.43 & $\mathbf{6 3 . 2 9}$ & 41.79 & 34.39 & 59.48 & 55.22 & 28.36 \\
$\mathrm{TiO}_{2}$ & 0.55 & 0.54 & 0.15 & $\mathbf{2 . 5 6}$ & 0.00 & 0.12 & 1.50 & 0.00 \\
$\mathrm{ZrO}_{2}$ & 0.00 & 0.00 & 0.00 & 0.09 & 0.42 & 0.00 & 0.04 & 0.00 \\
$\mathrm{SnO}_{2}$ & 0.00 & 0.00 & 0.26 & $\mathbf{1 . 1 8}$ & 0.51 & 0.20 & 0.58 & 0.06 \\
$\mathrm{Sc}_{2} \mathrm{O}_{3}$ & 0.00 & 0.00 & 0.00 & 0.14 & 0.10 & 0.16 & 0.12 & 0.00 \\
$\mathrm{MgO}$ & 0.00 & 0.00 & 0.00 & 0.05 & 0.00 & 0.00 & $\mathbf{0 . 0 6}$ & 0.00 \\
$\mathrm{MnO}$ & 17.02 & 11.88 & 9.42 & 7.05 & 17.08 & 15.39 & 11.49 & $\mathbf{1 8 . 7 2}$ \\
$\mathrm{FeO}$ & 2.52 & 8.44 & 6.31 & 10.02 & 0.13 & 0.52 & 4.71 & 0.04 \\
$\mathrm{Total}$ & 99.59 & 99.54 & 99.24 & 98.80 & 98.38 & 98.49 & 99.88 & 99.50 \\
& & & & & & & & \\
$\mathrm{~W}^{6+}(a p f u)$ & 0.063 & 0.025 & 0.000 & 0.009 & 0.000 & 0.000 & 0.000 & 0.000 \\
$\mathrm{Nb}^{5+}$ & 6.880 & 7.217 & 2.717 & 4.387 & 5.476 & 3.022 & 3.304 & 5.987 \\
$\mathrm{Ta}^{5+}$ & 0.980 & 0.667 & $\mathbf{5 . 2 2 2}$ & 3.087 & 2.480 & 4.896 & 4.400 & 1.990 \\
$\mathrm{Ti}^{4+}$ & 0.099 & 0.096 & 0.034 & 0.523 & 0.000 & 0.025 & 0.307 & 0.000 \\
$\mathrm{Zr}^{4+}$ & 0.000 & 0.000 & 0.000 & 0.012 & $\mathbf{0 . 0 5 4}$ & 0.000 & 0.005 & 0.000 \\
$\mathrm{Sn}^{4+}$ & 0.000 & 0.000 & 0.031 & $\mathbf{0 . 1 2 7}$ & 0.054 & 0.024 & 0.063 & 0.006 \\
$\mathrm{Sc}^{3+}$ & 0.000 & 0.000 & 0.000 & 0.032 & 0.023 & $\mathbf{0 . 0 4 1}$ & 0.028 & 0.000 \\
$\mathrm{Mg}^{2+}$ & 0.000 & 0.000 & 0.000 & 0.020 & 0.000 & 0.000 & $\mathbf{0 . 0 2 5}$ & 0.000 \\
$\mathrm{Mn}^{2+}$ & 3.457 & 2.366 & 2.421 & 1.621 & 3.832 & 3.910 & 2.835 & 4.034 \\
$\mathrm{Fe}^{2+}$ & 0.505 & 1.661 & 1.601 & $\mathbf{2 . 2 7 4}$ & 0.028 & 0.131 & 1.086 & 0.009 \\
\hline
\end{tabular}

Note: The following standards were used: $\mathrm{CoWO}_{4}(\mathrm{WM} \beta), \mathrm{MnNb}_{2} \mathrm{O}_{6}(\mathrm{MnK} \alpha, \mathrm{NbL} \alpha)$, $\mathrm{NiTa}_{2} \mathrm{O}_{6}(\mathrm{TaM} \alpha)$, rutile $(\mathrm{TiK} \alpha)$, zircon $(\mathrm{Zr} K \alpha)$, cassiterite (SnK $\left.\alpha\right)$, REE glass ( $\left.\mathrm{Sc} K \alpha\right)$,

$\mathrm{MgNb}_{2} \mathrm{O}_{6}(\mathrm{Mg} K \alpha)$, and almandine $(\mathrm{Fe} K \alpha)$. Compositions were recalculated on the basis of $24 \mathrm{O}$ apfu. The number of point compositions used in averaging is shown in brackets. Maximum values are shown in bold. monly black, and rarely brownish black or reddish brown.

The cassiterite composition ranges from 88.92 to 99.90 wt. \% $\mathrm{SnO}_{2}$ (Table 6); the lower value is reflected in the elevated contents of $\mathrm{Ta}_{2} \mathrm{O}_{5}+\mathrm{Nb}_{2} \mathrm{O}_{5}$ (9.51 wt.\%) and $\mathrm{MnO}$ (1.13 wt.\%). Ta ranges from 0.76 to $7.37 \mathrm{wt} . \%$ $\mathrm{Ta}_{2} \mathrm{O}_{5}$. $\mathrm{Nb}$ attains 2.18 wt. $\% \mathrm{Nb}_{2} \mathrm{O}_{5}$. Other substituent elements are $\mathrm{Fe}$ and $\mathrm{Mn}$. Cassiterite can contain $\mathrm{Ta}+$ $\mathrm{Nb}$ in solid solution as (1) an $(\mathrm{Fe}, \mathrm{Mn})(\mathrm{Ta}, \mathrm{Nb}) \mathrm{O}_{4}$ com-

\begin{tabular}{lcllc} 
TABLE 5. $\begin{array}{l}\text { UNIT-CELL DIMENSIONS AND DEGREE OF } \\
\text { ORDER OF COLUMBITE-TANTALITE FROM } \\
\text { THE LITTLE NAHANNI PEGMATITE GROUP }\end{array}$ \\
$\begin{array}{lclll}\text { Cirque- } \\
\text { dike }\end{array}$ & $a(\AA)$ & $b(\AA)$ & $c(\AA)$ & $Q$ \\
\hline $1 \mathrm{~N}$ & $14.407(2)$ & $5.7559(7)$ & $5.1035(8)$ & 0.88 \\
$2-1$ & $14.324(6)$ & $5.744(2)$ & $5.076(2)$ & 0.90 \\
$2-5$ & $14.339(7)$ & $5.749(1)$ & $5.076(1)$ & 0.85 \\
$2-9$ & $14.429(5)$ & $5.764(2)$ & $5.089(3)$ & 0.90 \\
$4-1$ & $14.417(2)$ & $5.7597(8)$ & $5.0989(7)$ & 0.91 \\
$4-1 c$ & $14.419(3)$ & $5.7628(9)$ & $5.095(1)$ & 0.94 \\
$4-1 b$ & $14.425(2)$ & $5.7622(9)$ & $5.0960(1)$ & 0.93 \\
$4-2 \mathrm{a}$ & $14.412(6)$ & $5.750(2)$ & $5.087(2)$ & 0.82 \\
$4 \mathrm{~W}-1$ & $14.390(4)$ & $5.7504(9)$ & $5.116(1)$ & 0.71 \\
10 & $14.426(3)$ & $5.762(1)$ & $5.0932(9)$ & 0.94 \\
10 & $14.422(2)$ & $5.7605(7)$ & $5.0944(7)$ & 0.94 \\
$10-1$ & $14.402(2)$ & $5.758(1)$ & $5.095(1)$ & 0.90 \\
$10-1$ & $14.420(2)$ & $5.7611(8)$ & $5.0880(8)$ & 0.94 \\
$10-1$ & $14.425(1)$ & $5.7622(7)$ & $5.0917(6)$ & 0.92 \\
\hline
\end{tabular}
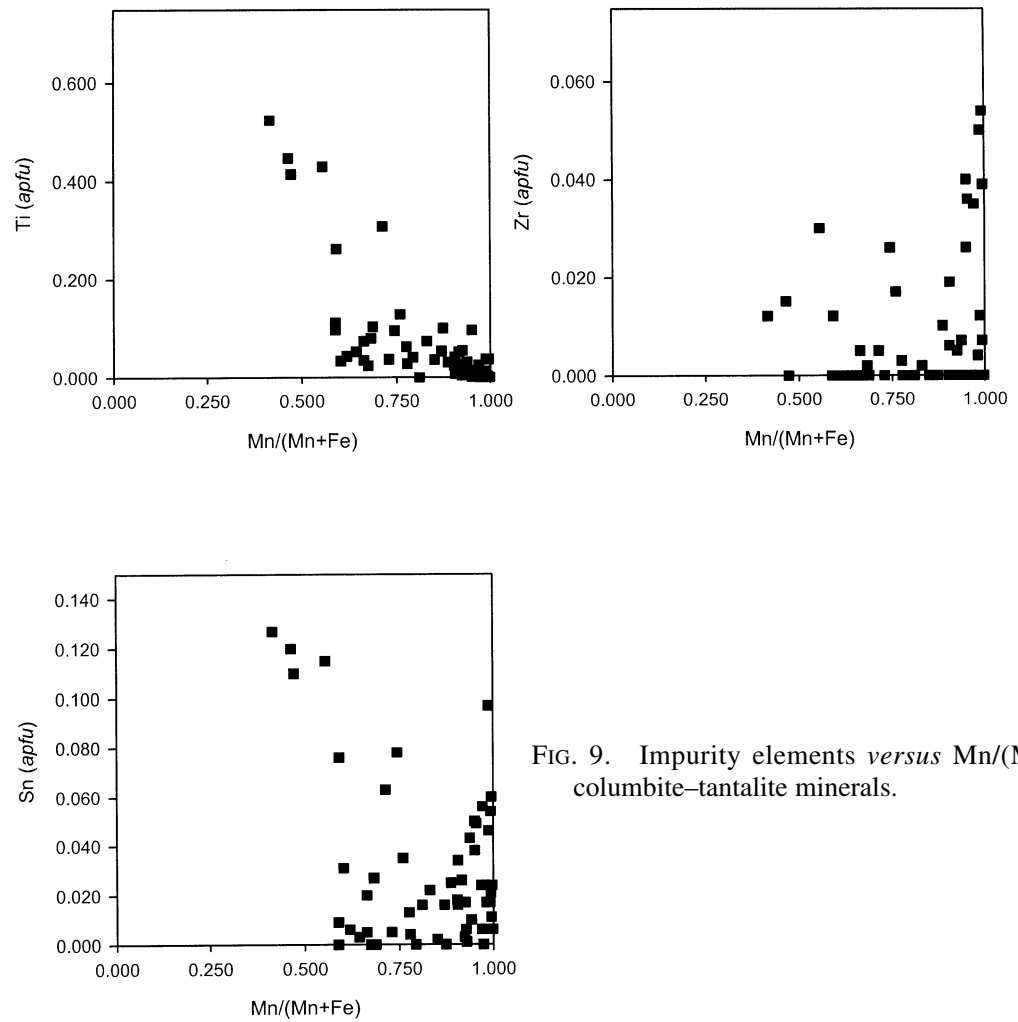

FIG. 9. Impurity elements versus $\mathrm{Mn} /(\mathrm{Mn}+\mathrm{Fe})$ for the columbite-tantalite minerals. 
ponent (very rare), (2) an $(\mathrm{Fe}, \mathrm{Mn})(\mathrm{Ta}, \mathrm{Nb})_{2} \mathrm{O}_{6}$ component (very common), and (3) as a $\square_{0.2}(\mathrm{Ta}, \mathrm{Nb})_{0.8} \mathrm{O}_{2}$ component. The slope of the regression line on a graph of $\mathrm{Mg}+\mathrm{Mn}+\mathrm{Fe}$ versus $\mathrm{Nb}+\mathrm{Ta}($ all apfu) is 0.42 (Fig. 13), which indicates that mechanism (2) is the most significant. However, the $y$ intercept of the data is slightly but significantly negative $(-0.0033)$, and the slope assuming only mechanism (2) is 0.38 , indicating that mechanism (3) plays a minor role.

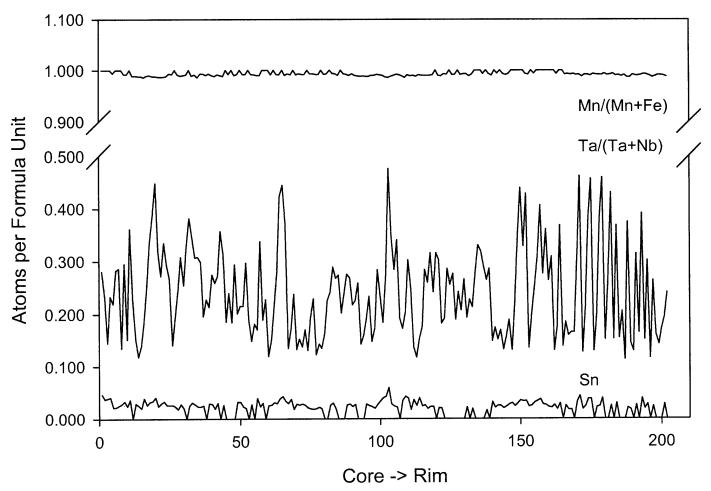

FIG. 10. Element variation, core-to-rim traverse across a columbite-tantalite crystal from cirque 4, dike 1 .

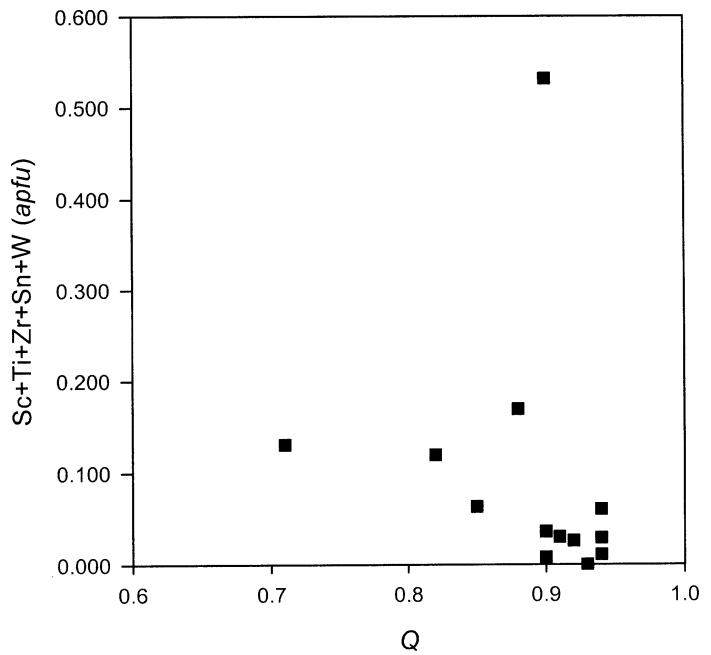

FIG. 11. Total concentration of impurity elements versus degree of cation order for the columbite-tantalite minerals (after Ercit et al. 1995). The outlier represents a sample from dike 2-1 with a very high Ti content.

\section{Tourmaline}

Tourmaline in schist and pegmatite occurs as finely disseminated grains, as prismatic aggregates of crystals up to $4 \mathrm{~mm}$ across and $2-3 \mathrm{~cm}$ long, and as fracturefillings. It is invariably black, with the exception of a green tourmaline from a dike in cirque 2 . In the schist, especially near the contact with the pegmatite, finegrained tourmaline also forms veinlets $(0.5 \mathrm{~cm}$ wide). In pegmatite, the mineral is confined primarily to the border zone, and in the wall and intermediate zones (collectively, inner zone). Some crystals are perpendicular to, and rooted in, the contact with the schist. Fracturefilling tourmaline, particularly in the border zone, normally radiates out of the fracture plane. Broken or bent discrete grains are found in the inner zone, but the surrounding phases remain intact. One peculiar feature is the presence of planar accumulations parallel to the contacts, along which tourmaline crystals are aligned. These are interpreted to be tourmalinized xenoliths incorporated into the pegmatite. The green tourmaline, approximately $1 \mathrm{~cm}$ across, is anhedral and intimately intergrown with spodumene and the feldspars.

Tourmaline compositions are aluminous (i.e., $\mathrm{Al}$ fully occupies the $Z$ site and is a minor constituent in the $Y$ site), and show some compositional variations (Table 7). In general, tourmaline crystals from the schist and border zone overlap in $\mathrm{Mg}, \mathrm{Al}, \mathrm{Li}, \mathrm{Fe}$, and $\mathrm{Mn}$ contents, and in the proportion of ${ }^{X} \square$. On average, they are higher in $\mathrm{Mg}$, but lower in $\mathrm{Al}, \mathrm{Li}, \mathrm{Mn}$ and $X \square$ values

TABLE 6. SELECTED AVERAGE COMPOSITIONS OF CASSITERITE FROM THE LITTLE NAHANNI PEGMATITE GROUP

\begin{tabular}{|c|c|c|c|c|c|c|}
\hline $\begin{array}{l}\text { Cirque- } \\
\text { dike }\end{array}$ & $0-4(5)$ & $0-4(7)$ & $5-6 \mathrm{~A}(1)$ & $0-4(3)$ & $2-1(2)$ & $2-8(2)$ \\
\hline $\mathrm{WO}_{3}$ (wt.\%) & 0.19 & 0.00 & 0.00 & 0.00 & 0.00 & 0.00 \\
\hline $\mathrm{Nb}_{2} \mathrm{O}_{5}$ & 1.44 & 2.18 & 2.14 & 0.00 & 0.19 & 1.04 \\
\hline $\mathrm{Ta}_{2} \mathrm{O}_{5}$ & 1.63 & 1.83 & 7.37 & 0.87 & 0.82 & 2.94 \\
\hline $\mathrm{TiO}_{2}$ & 0.00 & 0.12 & 0.00 & 0.48 & 0.00 & 0.06 \\
\hline $\mathrm{ZrO}_{2}$ & 0.00 & 0.00 & 0.41 & 0.00 & 0.00 & 0.00 \\
\hline $\mathrm{SnO}_{2}$ & 96.04 & 96.02 & 88.92 & 99.81 & 99.90 & 95.75 \\
\hline $\mathrm{MgO}$ & 0.06 & 0.06 & 0.00 & 0.00 & 0.06 & 0.09 \\
\hline $\mathrm{MnO}$ & 0.21 & 0.14 & 1.13 & 0.00 & 0.00 & 0.31 \\
\hline $\mathrm{FeO}$ & 0.03 & 0.57 & 0.00 & 0.00 & 0.00 & 0.18 \\
\hline Total & 99.62 & 100.93 & 99.97 & 101.16 & 100.96 & 100.75 \\
\hline $\mathrm{W}^{6+}(a p f u)$ & 0.002 & 0.000 & 0.000 & 0.000 & 0.000 & 0.000 \\
\hline $\mathrm{Nb}^{5+}$ & 0.033 & 0.048 & 0.049 & 0.000 & 0.005 & 0.024 \\
\hline $\mathrm{Ta}^{5+}$ & 0.022 & 0.025 & 0.101 & 0.012 & 0.011 & 0.040 \\
\hline $\mathrm{Ti}^{4+}$ & 0.000 & 0.005 & 0.000 & 0.018 & 0.000 & 0.002 \\
\hline $\mathrm{Zr}^{4+}$ & 0.000 & 0.000 & 0.010 & 0.000 & 0.000 & 0.000 \\
\hline $\mathrm{Sn}^{4+}$ & 1.920 & 1.887 & 1.780 & 1.968 & 1.979 & 1.906 \\
\hline $\mathrm{Mg}^{2+}$ & 0.004 & 0.004 & 0.000 & 0.000 & 0.004 & 0.007 \\
\hline $\mathrm{Mn}^{2+}$ & 0.009 & 0.006 & 0.048 & 0.000 & 0.000 & 0.013 \\
\hline $\mathrm{Fe}^{2+}$ & 0.001 & 0.023 & 0.000 & 0.000 & 0.000 & 0.008 \\
\hline $\mathrm{Ta} /(\mathrm{Ta}+\mathrm{Nb})$ & 0.405 & 0.339 & 0.673 & 1.000 & 0.710 & 0.630 \\
\hline $\mathrm{Mn} /(\mathrm{Mn}+\mathrm{Fe}$ & 0.865 & 0.200 & 1.000 & 0.000 & 0.000 & 0.634 \\
\hline$M^{5+}$ & 0.055 & 0.073 & 0.150 & 0.012 & 0.016 & 0.064 \\
\hline $\mathrm{M}^{2+}$ & 0.015 & 0.034 & 0.048 & 0.000 & 0.004 & 0.027 \\
\hline
\end{tabular}

Note: The following standards were used: $\mathrm{CoWO}_{4}(\mathrm{WM} \beta), \mathrm{MnNb}_{2} \mathrm{O}_{6}(\mathrm{MnK} \alpha, \mathrm{NbL} \alpha)$, $\mathrm{NiTa}_{2} \mathrm{O}_{6}(\mathrm{Ta} M \alpha)$, rutile $(\mathrm{Ti} K \alpha)$, zircon $(\mathrm{Zr} K \alpha)$, cassiterite $(\mathrm{Sn} K \alpha)$, REE glass ( $\left.\mathrm{Sc} K \alpha\right)$, $\mathrm{MgNb}_{2} \mathrm{O}_{6}(\mathrm{MgK} \alpha)$, and almandine $(\mathrm{Fe} K \alpha)$. Compositions were recalculated on the basis of $4 \mathrm{O}$ apfu. The number of point compositions used in averaging is shown 


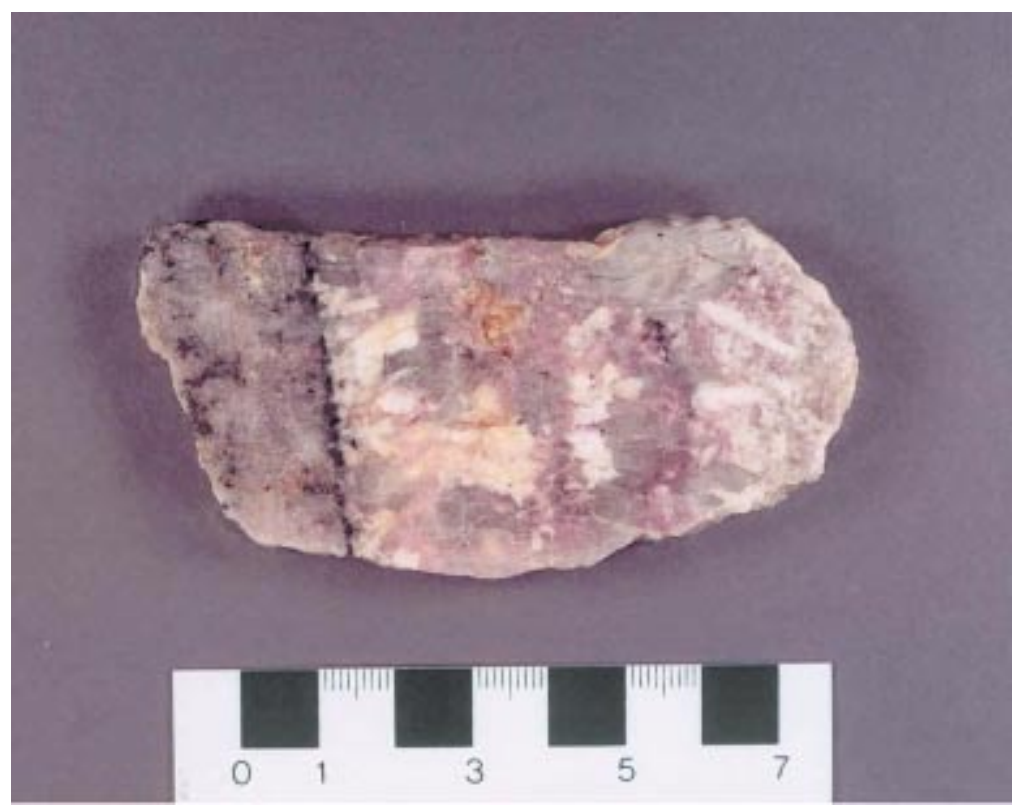

FIG. 12. Band of cassiterite between aplitic (or wall zone) Qtz-Lpd-Cst assemblage (left) and pegmatitic $\mathrm{Ab}-\mathrm{Qtz}-\mathrm{Lpd}$ (no cassiterite) assemblage to the right (sample from cirque 10 ; scale in $\mathrm{cm}$ ).

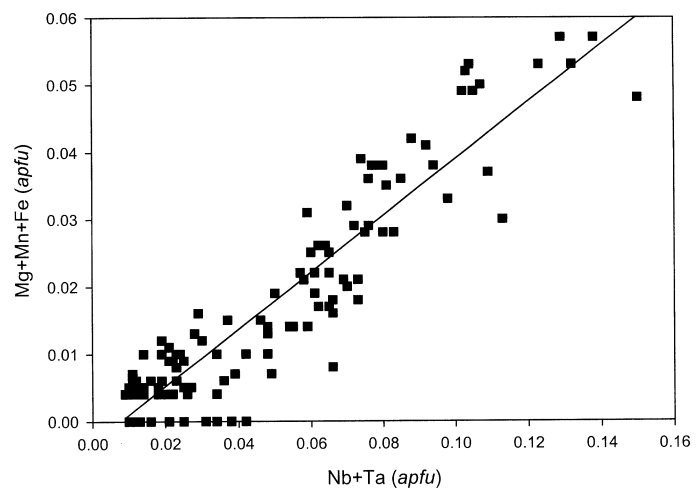

FIG. 13. Graph of $\mathrm{Mg}+\mathrm{Mn}+\mathrm{Fe}$ versus $\mathrm{Nb}+\mathrm{Ta}$ for cassiterite.

than those from the inner zone. The Ti contents are erratic, whereas $\mathrm{Fe}$ varies very little. Most crystals are schorl (Fig. 14). The crystals display a decreasing Na/ $(\mathrm{Na}+\square)$ value with an increasing $\mathrm{Al} /(\mathrm{Al}+\mathrm{Fe})$ value from the schist to the pegmatite inner zone.

Results from unit-cell determinations (Table 8) indicate that black tourmaline is intermediate to the dravite-schorl solid solutions, although it is closer to dravite (Fig. 15). All samples plot below the dravite-

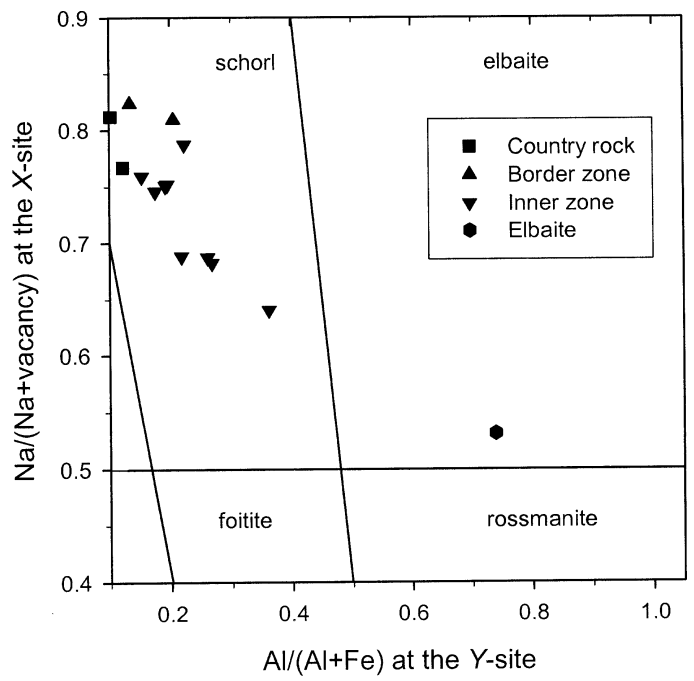

FIG. 14. $\mathrm{Na} /(\mathrm{Na}+\square)$ at the $X$ site versus $\mathrm{Al} /(\mathrm{Al}+\mathrm{Fe})$ at the $Y$ site for LNPG tourmalines.

schorl reference line, and seem to indicate a trend toward the elbaite-schorl join from tourmaline in the schist to that in the inner zone. Such a trend can be ex- 
plained by a coupled substitution involving $\mathrm{Ti}^{4+}+$ $(\mathrm{Mg}, \mathrm{Fe}, \mathrm{Mn})^{2+} \leftrightarrow \mathrm{Al}^{3+}+3 \mathrm{Li}^{+}$, or $2(\mathrm{Mg}, \mathrm{Fe})^{2+} \leftrightarrow \mathrm{Al}^{3+}+$ $\mathrm{Li}^{+}$, as limited substitution exists for compositions intermediate to the dravite and elbaite end-members (Chaudhry \& Howie 1976). Either proposed exchangemechanism is possible, since both sets of operators have a linear antithetic relationship. Furthermore, as mentioned previously, the tourmaline becomes richer in $\mathrm{Al}$ and $\mathrm{Li}$, but poorer in $\mathrm{Mg}$, and shows a decreasing $\mathrm{Na} /$ $(\mathrm{Na}+\square)$ value with an increasing $\mathrm{Al} /(\mathrm{Al}+\mathrm{Fe})$ value (Fig. 14) from the schist to the inner zone of the pegmatite dikes.

The measured unit-cell dimensions of the lone green tourmaline plot near the elbaite end-member, but are slightly above the reference line (Fig. 15). This depar-

TABLE 7. SELECTED AVERAGE COMPOSITIONS OF TOURMALINE FROM THE LITTLE NAHANNI PEGMATITE GROUP

\begin{tabular}{|c|c|c|c|c|c|}
\hline & $\begin{array}{c}\text { PT } 1(14) \\
\text { CR }\end{array}$ & $\begin{array}{c}\text { PT } 2(15) \\
\text { BZ }\end{array}$ & $\begin{array}{c}\text { PT } 3(48) \\
\text { IZ }\end{array}$ & $\begin{array}{l}\text { PT } 4(7) \\
\text { elbaite }\end{array}$ & $\begin{array}{c}\mathrm{PT} 5(2) \\
\text { foitite }\end{array}$ \\
\hline $\mathrm{SiO}_{2}$ (wt. \%) & 34.16 & 33.87 & 34.23 & 35.95 & 35.48 \\
\hline $\mathrm{TiO}_{2}$ & 1.05 & 0.78 & 0.60 & 0.00 & 0.14 \\
\hline $\mathrm{B}_{2} \mathrm{O}_{3}{ }^{*}$ & 10.33 & 10.32 & 10.33 & 10.70 & 10.49 \\
\hline $\mathrm{Al}_{2} \mathrm{O}_{3}$ & 32.92 & 33.03 & 34.21 & 38.28 & 35.95 \\
\hline $\mathrm{V}_{2} \mathrm{O}_{3}$ & 0.02 & 0.01 & 0.00 & 0.00 & 0.00 \\
\hline $\mathrm{Cr}_{2} \mathrm{O}_{3}$ & 0.01 & 0.00 & 0.00 & 0.00 & 0.00 \\
\hline $\mathrm{MgO}$ & 2.87 & 3.52 & 1.62 & 0.00 & 0.86 \\
\hline $\mathrm{CaO}$ & 0.51 & 0.71 & 0.43 & 0.13 & 0.09 \\
\hline $\mathrm{MnO}$ & 0.25 & 0.23 & 0.51 & 0.95 & 0.72 \\
\hline $\mathrm{FeO}$ & 11.50 & 11.21 & 11.64 & 6.19 & 10.97 \\
\hline $\mathrm{Li}_{2} \mathrm{O}$ & 0.31 & 0.20 & 0.40 & 1.32 & 0.38 \\
\hline $\mathrm{Na}_{2} \mathrm{O}$ & 2.20 & 2.16 & 2.02 & 2.59 & 1.30 \\
\hline $\mathrm{K}_{2} \mathrm{O}$ & 0.02 & 0.03 & 0.02 & 0.00 & 0.00 \\
\hline $\mathrm{H}_{2} \mathrm{O}^{*}$ & 3.19 & 3.18 & 3.25 & 3.18 & 3.62 \\
\hline $\mathrm{F}$ & 0.78 & 0.81 & 0.67 & 1.09 & 0.00 \\
\hline $\mathrm{O}=\mathrm{F}$ & -0.33 & -0.34 & -0.28 & -0.46 & 0.00 \\
\hline Total & 99.79 & 99.71 & 99.65 & 99.92 & 100.00 \\
\hline $\mathrm{Si}^{4+}(a p f u)$ & 5.750 & 5.707 & 5.758 & 5.838 & 5.877 \\
\hline $\mathrm{Ti}^{4+}$ & 0.133 & 0.099 & 0.076 & 0.000 & 0.017 \\
\hline $\mathrm{B}^{3+}$ & 3.000 & 3.000 & 3.000 & 3.000 & 3.000 \\
\hline $\mathrm{Al}^{3+}$ & 6.531 & 6.559 & 6.782 & 7.327 & 7.018 \\
\hline $\mathrm{V}^{3+}$ & 0.003 & 0.001 & 0.000 & 0.000 & 0.000 \\
\hline $\mathrm{Cr}^{3+}$ & 0.001 & 0.000 & 0.000 & 0.000 & 0.000 \\
\hline $\mathrm{Mg}^{2+}$ & 0.720 & 0.884 & 0.406 & 0.000 & 0.212 \\
\hline $\mathrm{Ca}^{2+}$ & 0.092 & 0.128 & 0.077 & 0.023 & 0.016 \\
\hline $\mathrm{Mn}^{2+}$ & 0.036 & 0.033 & 0.073 & 0.131 & 0.101 \\
\hline $\mathrm{Fe}^{2+}$ & 1.619 & 1.580 & 1.637 & 0.841 & 1.520 \\
\hline $\mathrm{Li}^{+}$ & 0.210 & 0.136 & 0.271 & 0.862 & 0.253 \\
\hline $\mathrm{Na}^{+}$ & 0.718 & 0.706 & 0.659 & 0.816 & 0.417 \\
\hline $\mathrm{K}^{+}$ & 0.004 & 0.006 & 0.004 & 0.000 & 0.000 \\
\hline $\mathrm{H}^{+}$ & 3.585 & 3.568 & 3.644 & 3.440 & 4.000 \\
\hline $\mathrm{F}^{-}$ & 0.415 & 0.432 & 0.356 & 0.560 & 0.000 \\
\hline
\end{tabular}

Note: The following standards were used: bytownite (AIK $\alpha, \operatorname{SiK} \alpha)$, rutile $(\mathrm{Ti} K \alpha), \mathrm{VP}_{2} \mathrm{O}_{7}(\mathrm{~V} K \alpha)$, nichromite $(\mathrm{Cr} K \alpha)$, enstatite $(\mathrm{MgK} \alpha)$, gehlenite $(\mathrm{CaK} \alpha)$, tephroite $(\mathrm{MnK} \alpha)$, almandine $(\mathrm{FeK} \alpha)$, Na-amphibole $(\mathrm{Na} K \alpha)$, microcline $(\mathrm{KK} \alpha)$, and phlogopite $(F K \alpha)$. BZ = Border Zone, $\mathrm{CR}=$ Country Rock, $\mathrm{IZ}=$ Inner Zone. Analyses were recalculated on the basis of 31 anions assuming $4(\mathrm{OH}, \mathrm{F})$. The number of point compositions used in averaging is shown in brackets. Maximum values are shown in bold. Sc and Sn were sought but not detected. *Determined by stoichiometry. ture is most likely due to the elevated content of $\mathrm{Fe}^{2+}$ in the elbaite.

Two compositions of the rim of one sample from the inner zone of dike 3-2 plot in the foitite field (the other ten data-points of this sample plot as schorl) on an $\mathrm{Al} /$ $(\mathrm{Al}+\mathrm{Fe})$ versus $\mathrm{Na} /(\mathrm{Na}+\square)$ diagram. The Little Nahanni sample may represent the second reported Canadian occurrence of foitite, the first reported being from the Tanco pegmatite (Selway et al. 2000).

\section{Phosphates}

Apatite is the most abundant phosphate in the LNPG, occurring in interstices and as inclusions in the feldspars in all zones, with the exceptions of the aplitic zone and quartz core. Some crystals are found along the selvages of calcite-filled veinlets and cross-cutting fractures. The mineral is commonly zoned, with a green core and a purplish rim; other hues are colorless and blue. Its habit varies from discrete euhedra to acicular aggregates to masses. The chemical composition of the primary apa-

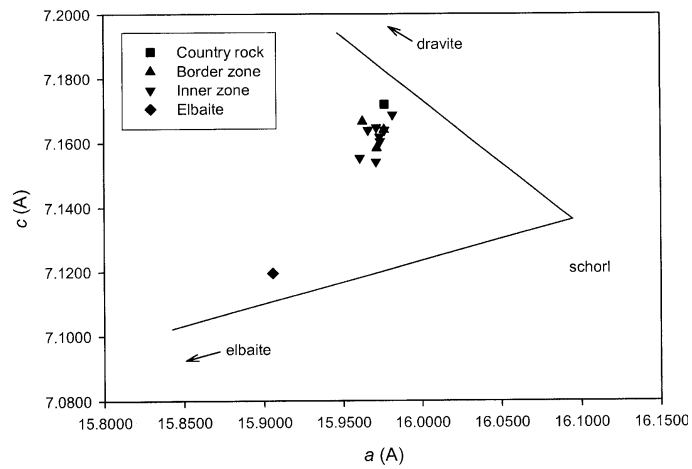

FIG. 15. The cell parameters $c$ versus $a(\AA)$ for the LNPG tourmalines.

TABLE 8. UNIT-CELL DIMENSIONS OF TOURMALINE FROM THE LITTLE NAHANNI PEGMATITE GROUP

\begin{tabular}{lcccc}
\hline Cirque-dike & Type & $a(\AA)$ & $c(\AA)$ & $V\left(\AA^{3}\right)$ \\
\hline $1 \mathrm{~N}$ & Country rock & $15.9765(1)$ & $7.1717(1)$ & $1585.32(1)$ \\
$1 \mathrm{~N}-7$ & $\mathrm{BZ}$ & $15.9626(1)$ & $7.1665(1)$ & $1581.43(2)$ \\
3 & $\mathrm{BZ}$ & $15.9763(1)$ & $7.1639(1)$ & $1583.57(2)$ \\
$5-5 \mathrm{~B}$ & $\mathrm{BZ}$ & $15.9716(1)$ & $7.1583(1)$ & $1581.38(2)$ \\
$1 \mathrm{~N}-5$ & $\mathrm{Z}$ & $15.9713(1)$ & $7.1646(1)$ & $1582.73(2)$ \\
$1 \mathrm{~N}-11 \mathrm{~A}$ & $\mathrm{IZ}$ & $15.9734(1)$ & $7.1618(1)$ & $1582.51(2)$ \\
$1 \mathrm{~N}-27$ & $\mathrm{IZ}$ & $15.9765(1)$ & $7.1638(1)$ & $1583.562(7)$ \\
$1^{\wedge} 2 \mathrm{t}$ & $\mathrm{Z}$ & $15.9711(1)$ & $7.1540(1)$ & $1580.338(8)$ \\
2 & $\mathrm{IZ}$ & $15.9817(1)$ & $7.1685(1)$ & $1585.62(1)$ \\
2 & $\mathrm{Z}$ & $15.9737(2)$ & $7.1604(1)$ & $1582.27(2)$ \\
3 & $\mathrm{IZ}$ & $15.9661(1)$ & $7.1638(1)$ & $1581.51(2)$ \\
$5-1$ & $\mathrm{ZZ}$ & $15.9609(1)$ & $7.1552(1)$ & $1578.57(3)$ \\
$1 \mathrm{~S}$ & elbaite & $15.9055(1)$ & $7.1195(1)$ & $1559.81(2)$ \\
\hline
\end{tabular}

Note: $\mathrm{BZ}=$ Border Zone, $\mathrm{IZ}=$ Inner Zones 
tite ranges from fluorapatite to hydroxylapatite with highly variable Mn contents (maximum 5.03 wt.\% $\mathrm{MnO})$. In general, the green crystals show the lowest Mn contents, and the purple variety, the highest.

Lithiophilite, $\mathrm{Li}\left(\mathrm{Mn}^{2+}, \mathrm{Fe}^{2+}\right) \mathrm{PO}_{4}$, is the second most abundant phosphate mineral. With regard to occurrence, habit, composition and products of alteration, two different types have been distinguished. The first occurs in orange- to salmon-colored nodules up to $20 \mathrm{~cm}$ in diameter enclosed by quartz and plagioclase in the inner wall zone. The lithiophilite is essentially clear and colorless; the color of the nodules is due to the alteration products, light red triploidite, $\left(\mathrm{Mn}^{2+}, \mathrm{Fe}^{2+}\right)_{2}\left(\mathrm{PO}_{4}\right)(\mathrm{OH})$, and a yellow to pale orange $\mathrm{Ca}-\mathrm{Mn}$ phosphate mineral. Compositionally, the lithiophilite is close to the endmember; $\mathrm{Mn} /(\mathrm{Mn}+\mathrm{Fe})$ ranges from 0.95 to 0.97 (Table 9).

The lithiophilite crystals are divided into relatively unaltered islands of lithiophilite surrounded and invaded by irregular masses of triploidite $[\mathrm{Mn} /(\mathrm{Mn}+\mathrm{Fe})$ in the range 0.96 to 0.98; Table 9], the unknown $\mathrm{Ca}-\mathrm{Mn}$ phosphate mineral, and Mn-rich hydroxylapatite. Electronmicroprobe analyses (Table 9) show that the unknown $\mathrm{Ca}-\mathrm{Mn}$ phosphate mineral is fairfieldite-like in composition, with the approximate formula $(\mathrm{Ca}, \mathrm{Mn}, \mathrm{Fe})_{3}\left(\mathrm{PO}_{4}\right)_{2}$
-2 $\mathrm{H}_{2} \mathrm{O}$. Crystal boundaries in contact with the surrounding quartz are heavily altered to oxides of $\mathrm{Mn}$ and Fe.

The second type of lithiophilite occurs as dark brown to black, euhedral to subhedral crystals up to $3 \mathrm{~cm}$ long or as veinlets parallel to dike contacts (within the wall zone). This type of lithiophilite is relatively rich in $\mathrm{Fe}$ $[\mathrm{Mn} /(\mathrm{Mn}+\mathrm{Fe})$ in the range 0.75 to 0.85 ; samples from the ridge between cirques 1 and 2 and dike 2-7 show higher Fe contents than samples from the ridge between cirques $1 \mathrm{~N}$ and $1 \mathrm{~S}$; Table 9]. For this type, the sequence of alteration is as follows: lithiophilite $\rightarrow$ triploidite $\rightarrow$ purpurite, $\mathrm{Mn}^{3+} \mathrm{PO}_{4} \rightarrow \mathrm{Ca}-\mathrm{Mn}$ phosphate $\rightarrow$ Mn-rich hydroxylapatite and fluorapatite. Triploidite is relatively rare and occurs as small isolated grains and veins. Grain margins and fracture walls are altered to purpurite. The unknown $\mathrm{Ca}-\mathrm{Mn}$ phosphate mineral is rare, except in minor veins with triploidite, apatite, and calcite. Electron-microprobe analyses show that the Mn content of the apatite ranges from approximately 3.5 to $13.0 \mathrm{wt}$.\% MnO (Table 9, anal. 1 and 2). Grain boundaries against quartz are altered to oxides of $\mathrm{Mn}$ and $\mathrm{Fe}$.

Rare montebrasite occurs as anhedral grains surrounded by albite and lepidolite. Electron-microprobe analyses show that elements other than $\mathrm{Li}, \mathrm{F}, \mathrm{Al}$, and $\mathrm{P}$ are found only at trace levels in the montebrasite, and

TABLE 9. SELECTED COMPOSITIONS OF PHOSPHATE MINERALS FROM THE LITTLE NAHANNI PEGMATITE GROUP

\begin{tabular}{|c|c|c|c|c|c|c|c|c|c|}
\hline $\begin{array}{l}\text { Mineral } \\
\text { Cirque-dike }\end{array}$ & $\begin{array}{c}\text { apatite } \\
2-7 \\
\end{array}$ & $\begin{array}{c}\text { apatite } \\
1^{\wedge} 2\end{array}$ & $\begin{array}{c}\text { apatite } \\
5(4)\end{array}$ & $\begin{array}{c}\text { lithiophilite } \\
5-8(12)\end{array}$ & $\begin{array}{l}\text { lithiophilite } \\
1^{\wedge} 22-7(4)\end{array}$ & $\begin{array}{l}\text { lithiophilite } \\
1 N^{\wedge} 1 S(3)\end{array}$ & $\begin{array}{l}\text { triploidite } \\
5(4)\end{array}$ & $\begin{array}{c}\text { triploidite } \\
2-7 \\
\end{array}$ & $\begin{array}{c}\text { unknown } \\
5(10)\end{array}$ \\
\hline Type & $\mathrm{T} 2$ & $\mathrm{~T} 2$ & & $\mathrm{~T} 1$ & $\mathrm{~T} 2$ & $\mathrm{~T} 2$ & $\mathrm{~T} 1$ & $\mathrm{~T} 2$ & $\mathrm{~T} 1$ \\
\hline $\mathrm{SO}_{3}$ & 0.07 & 0.04 & 0.00 & - & - & - & 0.00 & 0.27 & - \\
\hline $\mathrm{P}_{2} \mathrm{O}_{5}$ & 41.13 & 39.15 & 41.81 & 45.40 & 46.04 & 45.78 & 32.10 & 31.70 & 38.90 \\
\hline $\mathrm{SiO}_{2}$ & 0.00 & 0.17 & 0.00 & - & - & - & 0.00 & 0.19 & - \\
\hline $\mathrm{MgO}$ & 0.00 & 0.00 & 0.00 & 0.01 & 0.11 & 0.00 & - & - & - \\
\hline $\mathrm{CaO}$ & 52.46 & 42.25 & 51.60 & 0.09 & 0.06 & 0.07 & 1.41 & 0.12 & 16.99 \\
\hline $\mathrm{MnO}$ & 3.49 & 13.04 & 3.78 & 43.18 & 33.95 & 38.04 & 60.11 & 59.92 & 34.58 \\
\hline $\mathrm{FeO}$ & 0.03 & 0.73 & 0.00 & 1.62 & 11.62 & 7.04 & 1.43 & 2.36 & 1.43 \\
\hline $\mathrm{Li}_{2} \mathrm{O}^{*}$ (wt.\%) & - & - & - & 9.53 & 9.67 & 9.60 & - & - & - \\
\hline $\mathrm{H}_{2} \mathrm{O}^{*}$ & 0.02 & 1.17 & 0.00 & - & - & - & 3.81 & 3.79 & 9.87 \\
\hline $\mathrm{F}$ & 3.67 & 1.08 & 4.08 & - & - & - & 0.51 & 0.51 & - \\
\hline $\mathrm{O}=\mathrm{F}$ & -1.55 & -0.45 & -1.72 & - & - & - & -0.21 & -0.21 & - \\
\hline Total & 99.38 & 97.29 & 99.55 & 99.83 & 101.45 & 100.53 & 99.15 & 98.64 & 101.77 \\
\hline $\mathrm{S}^{6+}(a p f u)$ & 0.004 & 0.003 & 0.000 & - & - & - & 0.000 & 0.008 & - \\
\hline $\mathrm{P}^{5+}$ & 2.972 & 2.952 & 2.999 & 1.003 & 1.002 & 1.004 & 1.006 & 0.999 & 2.000 \\
\hline $\mathrm{Si}^{4+}$ & 0.000 & 0.015 & 0.000 & - & - & - & 0.000 & 0.007 & - \\
\hline $\mathrm{Mg}^{2+}$ & 0.000 & 0.000 & 0.000 & 0.000 & 0.004 & 0.000 & - & - & - \\
\hline $\mathrm{Ca}^{2+}$ & 4.797 & 4.032 & 4.684 & 0.003 & 0.002 & 0.002 & 0.056 & 0.005 & 1.106 \\
\hline $\mathrm{Mn}^{2+}$ & 0.252 & 0.984 & 0.271 & 0.954 & 0.739 & 0.835 & 1.885 & 1.889 & 1.779 \\
\hline $\mathrm{Fe}^{2+}$ & 0.002 & 0.054 & 0.000 & 0.035 & 0.250 & 0.153 & 0.044 & 0.073 & 0.073 \\
\hline $\mathrm{Li}^{+}$ & - & - & - & 1.000 & 1.000 & 1.000 & - & - & - \\
\hline $\mathrm{H}^{+}$ & 0.009 & 0.696 & 0.000 & - & - & - & 0.940 & 0.940 & 4.000 \\
\hline $\mathrm{F}^{-}$ & 0.991 & 0.304 & 1.093 & - & - & - & 0.060 & 0.060 & - \\
\hline $\mathrm{O}^{2-}$ & 12.009 & 12.696 & 11.907 & 4.000 & 4.000 & 4.000 & 4.940 & 4.940 & 9.957 \\
\hline
\end{tabular}

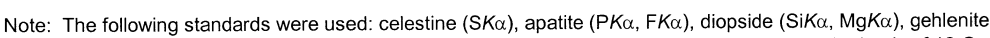
$(\mathrm{CaK} \alpha)$, tephroite $(\mathrm{MnK} \alpha)$, and almandine $(\mathrm{Fe} K \alpha)$. Apatite compositions were recalculated on the basis of $12 \mathrm{O}$ and $1(\mathrm{OH}, \mathrm{F})$ apfu, lithiophilite compositions were recalculated on the basis of $4 \mathrm{O}$ apfu, triploidite compositions were renormalized on the basis of $4 \mathrm{O}$ and $1(\mathrm{OH}, \mathrm{F})$ apfu, and the compositions of the unknown phase was recalculated on the basis of $5 \mathrm{P}^{5+}$ and $2 \mathrm{H}_{2} \mathrm{O}$ apfu. The number of point compositions used in averaging is shown in brackets. $\mathrm{Cl}, \mathrm{V}, \mathrm{Ce}$, and $\mathrm{Nd}$ were sought but not detected.

*Determined by stoichiometry. 
that $\mathrm{F}$ contents range from approximately 0.20 to 0.33 apfu. The grains seem to be extensively altered to Mnbearing fluorapatite (Table 9, anal. 3).

\section{Beryl}

Beryl, a minor constituent throughout the Little Nahanni Pegmatite Group, varies from colorless to white to bluish, and from being equant to anhedral crystals up to $6 \mathrm{~cm}$ long and $4 \mathrm{~cm}$ wide (generally approximately 1 to $2 \mathrm{~cm}$ across). Crystals commonly form at the contact between the wall and intermediate units, where the minerals are intergrown primarily with coarse, anhedral quartz and K-feldspar, and subordinately with patchy, fine-grained lepidolite and fine-grained, granular (saccharoidal) albite. Beryl crystals (including the "aquamarine" variant) are also found with smoky quartz and K-feldspar in calcite-filled vugs, and they host inclusions of muscovite, fragments of albite-bearing veinlets and uranmicrolite.

The Little Nahanni beryl contains appreciable traceelement concentrations: 0.14 to 0.65 wt. $\% \mathrm{Li}_{2} \mathrm{O}, 0.71$ to 1.69 wt. $\% \mathrm{Na}_{2} \mathrm{O}$, and 0.07 to 0.93 wt. $\% \mathrm{Cs}_{2} \mathrm{O}$. The colorless crystals have the highest $\mathrm{Na}$ content, whereas the rim of a translucent crystal is rich in Cs. Only the bluish beryl in the vug has elevated contents of $\mathrm{Mg}(0.45 \mathrm{wt} . \%$
$\mathrm{MgO})$ and $\mathrm{Fe}(0.31$ wt.\% $\mathrm{FeO})$. Following the classification scheme of Cerný (1975), all analyzed crystals of beryl fall into the sodic-lithian category.

\section{Garnet}

Garnet-group minerals are rare, even in the aplitic part of the composite pegmatite-aplite bodies. The mineral exhibits two modes of occurrence: interstitially and as massive pods. In the former, garnet occurs as anhedral to euhedral, orange-red to reddish brown crystals in the border zone, at or very close to the pegmatite-wallrock contact. The crystals, varying in size from several $\mathrm{mm}$ to $2.5 \mathrm{~cm}$, are interstitial to quartz, muscovite, albite and schorl. In some cases, the garnet overgrows tourmaline, but is in turn overgrown by muscovite.

Garnet of the second mode of occurrence forms coarse-grained pods (up to $2.5 \mathrm{~cm}$ ) associated with fineto medium-grained albite and quartz, most commonly in the aplitic part of the composite pegmatite-albite bodies. The larger crystals are usually glass-like and heavily fractured.

Chemically, all grains consist of spessartine (Table 10). Where compositional zoning is present, the Mn content generally increases from core to rim, the $\mathrm{Ca}$ content decreases and the Fe content remains relatively constant. Titanium attains 0.27 wt. $\% \mathrm{TiO}_{2}$.

\section{Zeolites}

Several members of the zeolite group have been found. They occur as late-stage minerals lining vugs, overgrowing all minerals except calcite in calcite-filled fractures. The species were identified visually and with powder X-ray diffraction and energy-dispersion X-ray data. Stellerite, chabazite-Ca, and stilbite-Ca are commonly associated with apatite and beryl in late-stage fractures and pockets. Laumontite and heulandite-Ca occur in albite-rich units in vugs and voids left by altered spodumene.

\section{Other accessory minerals}

Galena occurs as minute inclusions and as discrete grains within feldspar grains. Sphalerite forms anhedral blebs associated with albite and K-feldspar. Pyrrhotite and pyrite are associated with schorl and garnet along the pegmatite - host-rock contact. Tantalian rutile (Table 11) occurs as rare discrete grains and as inclusions in columbite-group minerals. Uranmicrolite is included in apatite and in beryl. Small, anhedral, purple crystals of fluorite up to $1 \mathrm{~mm}$ are present in a calcitefilled miarolitic cavity. Orange-yellow to orange-brown helvite forms tetrahedral crystals on "skeletal", etched $\mathrm{K}$-feldspar in calcite-filled pockets in specimens from cirque $1 \mathrm{~N}$, where it is associated with apatite, beryl, albite and chabazite.
Note: The following standards were used: apatite (PK $\alpha)$, almandine ( $\mathrm{SiK} \alpha$, AIK $\alpha, \mathrm{Fe} K \alpha, \mathrm{CaK} \alpha)$, rutile $(\mathrm{Ti} K \alpha)$, pyrope $(\mathrm{Mg} K \alpha)$, and tephroite $(\mathrm{Mn} K \alpha)$. Garnet compositions were recalculated on the basis of 8 cations and $12 \mathrm{O} a p f u$. The number of point compositions used in averaging is shown in brackets. $\mathrm{Na}, \mathrm{Zr}$, and $\mathrm{Sn}$ were sought but not found. 


\section{DISCUSSION}

\section{Chemical evolution of the minerals}

From the border through the inner (wall and intermediate) zone to the core zone, the mineralogical association changes from columbite-tantalite \pm mica \pm tourmaline, through spodumene + cassiterite + phosphate + beryl + mica \pm tourmaline, to spodumene \pm cassiterite. This trend continues to fluorite + calcite + zeolite \pm mica \pm apatite \pm beryl in the miarolitic cavities. The composition of the rock-forming minerals shows systematic trends with, in general terms, an increase in $\mathrm{Al}, \mathrm{Mn}, \mathrm{Rb}$, and $\mathrm{Cs}$, and a decrease in $\mathrm{Mg}$ and Fe. These changes are clearly displayed by tourmaline compositions, with an increase in $\mathrm{Al}$ and a decrease in $\mathrm{Mg}$ from the border through the inner to the pocket zone. Although other minerals lack this chemical-spatial correlation, the above-mentioned trends indicate fractionation of elements in an evolving pegmatite-forming melt (Černý et al. 1985). Thus in concert with the mineralogical changes, the bulk of the residual melts became richer in $\mathrm{Li}, \mathrm{Be}, \mathrm{F}, \mathrm{P}, \mathrm{Sn}$, and $\mathrm{Ta}$ and poorer in $\mathrm{B}$ and $\mathrm{Nb}$ as the main stage of pegmatite evolution was approached. The increase of these elements reflects the high solubility of Ta in F-rich melts (e.g., Keppler 1993, Linnen 1998), the incompatible characteristics of Sn, a lack of $\mathrm{Ca}$ to form $(\mathrm{Ca}, \mathrm{F})$-based minerals, and a strong affinity of $\mathrm{F}$ for the melt. Precipitation of spodumene, cassiterite, montebrasite, beryl, and mica in the inner and core zones depleted the melt in $\mathrm{Li}, \mathrm{Be}, \mathrm{F}, \mathrm{P}$ and $\mathrm{Sn}$. Consequently, only traces of these elements are found in the pocket zone.

\section{Volatile phase}

Indeed, the presence of a chilled-margin-like aphanitic aplite border zone and the lack of books of muscovite in the border zone, and the minor exomorphism (other than B to form tourmaline), suggest that the Little Nahanni pegmatite-forming melt was initially $\mathrm{H}_{2} \mathrm{O}$-undersaturated. High activities of $\mathrm{P}$ also increase $\mathrm{H}_{2} \mathrm{O}$ solubility in granitic melts (Huffman et al. 1986), and removal of $\mathrm{P}$ decreases the solubility of $\mathrm{H}_{2} \mathrm{O}$ in the melt. Thus the felsic melts from which the Little Nahanni pegmatite solidified apparently were not $\mathrm{H}_{2} \mathrm{O}$-saturated until the late stages of evolution. It is likely that the small size of the dikes, thus the small volume of the injected melt, did not facilitate the development of a hydrous phase across the dikes, probably owing to a rather rapid crystallization (as shown by the moderate degree of order in some columbite-tantalite crystals). The melt did eventually achieve $\mathrm{H}_{2} \mathrm{O}$ saturation, as indicated by the formation of miarolitic cavities.

With regard to the genesis of tourmaline in the Little Nahanni pegmatites and its implication for the presence of B in the early felsic melt, texturally some of the crystals are magmatic and most likely late. Although the tourmaline grains have a composition and cell dimensions similar to those of tourmaline in the country rock in a few instances (Figs. 14, 15), the chemical evolution of the majority of the tourmaline parallels that of the rock-forming minerals, thus suggesting that not all tourmaline crystals are metasomatic or subsolidus. We propose that an initial, and short-lived, exchange between newly emplaced pegmatite-derived fluid and the host biotite schist occurred and resulted in tourmaline (dravite-schorl) in the exocontact zones. After precipitation of the early $\mathrm{Fe}-\mathrm{Mg}$-rich tourmaline, the residual fluid became depleted in those elements.

\section{Late-stage processes}

Several lines of evidence show that late-stage fluidrock interaction took place at subsolidus conditions. One or more of quartz, microcline, tourmaline, beryl, garnet, and mica are found in the miarolitic cavities, veins, and contact zones. The development of ordered perthitic $\mathrm{K}$-feldspar is attributed largely to aqueous fluids that rearranged the $\mathrm{Al}-\mathrm{Si}$ distribution in the tetrahedral framework in the initially disordered crystals (Martin

TABLE 11. SELECTED AVERAGE COMPOSITIONS OF RUTILE FROM THE LITTLE NAHANNI PEGMATITE GROUP

\begin{tabular}{lrrr}
\hline Cirque-dike & $1 \mathrm{~N}$ & $2-1$ & $2-1$ \\
& $(3)$ & $(5)$ & $(5)$ \\
\hline $\mathrm{Nb}_{2} \mathrm{O}_{5}$ (wt.\%) & $\mathbf{8 . 0 3}$ & 6.94 & 7.73 \\
$\mathrm{Ta}_{2} \mathrm{O}_{5}$ & $\mathbf{3 4 . 5 2}$ & 30.35 & 29.50 \\
$\mathrm{Sc}_{2} \mathrm{O}_{3}$ & $\mathbf{0 . 0 3}$ & 0.01 & 0.01 \\
$\mathrm{TiO}_{2}$ & 45.68 & $\mathbf{5 2 . 2 5}$ & 51.42 \\
$\mathrm{SnO}_{2}$ & $\mathbf{2 . 5 0}$ & 1.90 & 2.33 \\
$\mathrm{MnO}$ & 0.00 & 0.03 & $\mathbf{0 . 0 9}$ \\
$\mathrm{FeO}_{\mathrm{Total}}$ & $\mathbf{8 . 9 0}$ & 8.01 & 8.14 \\
& 99.65 & 99.50 & 99.21 \\
$\mathrm{Nb}^{5+}(a p f u)$ & $\mathbf{0 . 0 6 5}$ & 0.055 & 0.061 \\
$\mathrm{Ta}^{5+}$ & $\mathbf{0 . 1 7 0}$ & 0.143 & 0.142 \\
$\mathrm{Sc}^{3+}$ & 0.000 & 0.000 & 0.000 \\
$\mathrm{Ti}^{4+}$ & 0.620 & $\mathbf{0 . 6 8 0}$ & 0.669 \\
$\mathrm{Mn}^{2+}$ & 0.000 & 0.001 & 0.001 \\
$\mathrm{Fe}^{2+}$ & $\mathbf{0 . 1 3 4}$ & 0.117 & 0.120 \\
\hline
\end{tabular}

Note: The following standards were used: $\mathrm{MnNb}_{2} \mathrm{O}_{6}(\mathrm{MnK} \alpha, \mathrm{Nb} L \alpha), \mathrm{NiTa}_{2} \mathrm{O}_{6}(\mathrm{TaM} \alpha)$, rutile (TiK $\alpha)$, cassiterite $(\mathrm{SnK} \alpha)$, REE glass $(\mathrm{ScK} \alpha)$, and almandine $(\mathrm{FeK} \alpha)$. Compositions were recalculated on the basis of $2 \mathrm{O} a p f u$. The number of point compositions used in averaging is shown in brackets. Maximum values are shown in bold. $\mathrm{Mg}$ and $\mathrm{W}$ were sought but not detected. 
1982). However, most K-feldspar crystals are between 60 and $75 \%$ ordered, suggesting that the process was sluggish, perhaps because the temperature fell quickly below that needed to promote ordering. Furthermore, all zeolites identified are Ca-bearing minerals, and this fact, together with the presence of apatite in calcite pods, suggest some degree of infiltration or circulation of fluids between the host rock and the pegmatites. Beryl in miarolitic cavities is richer in $\mathrm{Mg}$ than the earlier-formed crystals in the main body of the pegmatite. Low-temperature fluid-rock interactions affected the pegmatites almost in their entirety, in all parts of the bodies across their zonal sequences, albeit not everywhere. The presence of veins containing tourmaline, beryl, and other accessory minerals in the pegmatite suggests that fracturing occurred prior to the final disappearance of residual fluids, which still carried enough elements to form these minerals.

The limited extent of replacement phenomena in the schist indicate that most of the residual fluids from crystallization reacted back with the solidified or solidifying pegmatites. This retograde fluid-rock interaction is what Jahns \& Burnham (1969) referred to as "stew(ing) in its own juices". The slightly contaminated residual aqueous fluid from which the subsolidus phases deposited is thus most likely rich in $\mathrm{Li}, \mathrm{B}, \mathrm{F}, \mathrm{Mg}, \mathrm{Si}$, and $\mathrm{Fe}$. For those reasons mentioned previously, the first three elements were most likely inherited from the felsic melt. On the other hand, $\mathrm{Mg}$ and $\mathrm{Fe}$ were leached from the country rocks by circulating residual fluids en route to the main body of the pegmatite; the felsic melt from which the pegmatite crystallized is very evolved and depleted in these elements.

\section{Characteristics of the melts and remaining questions}

The occurrence of distinct spodumene (almost free of lepidolite) and lepidolite (free of spodumene) pegmatites and their respective accessory minerals imply two compositionally distinct felsic melts. The spodumene-bearing pegmatite most probably solidified from a Li-rich, F-poor and P-poor melt, whereas the lepidolite-bearing pegmatite formed from a Li-rich, Frich, P-rich melt. These elements are required to form and stabilize the observed assemblage of minerals (see London 1987, Černý \& Burt 1984). The paramount questions are thus: are the melts comagmatic? If so, what are the physical and chemical mechanisms by which the initially homogeneous melts differentiate into two distinct batches of liquid? Furthermore, the close spatial relationships between the two types of pegmatite suggest a crudely synchronous emplacement. This field relationship points to pooling of two chemically distinct liquids in the same magma chamber, which were then ejected almost simultaneously. Can a dynamic magma chamber produce such compositionally stratified liquids with subtle differences in density and fluid- ity? And finally, what causes the banding in the pegmatites? These are some of the questions to be addressed in subsequent papers.

\section{ACKNOWLEDGEMENTS}

The authors thank E. Ray and B. Ernewein for logistical support and legal advice throughout the study. We also thank L. Kelly for administrative work and for organizing the 1993 field season. In addition, we acknowledge the following individuals for their help in the field: L. Kelly (1992, 1993), A.E. Lam (1993, 1994, 1995), S.C. Shaw (1995), and K. Simpson (1995). More recently, B. Pemberton helped with data acquisition and analysis, and K. Parker edited the final manuscript. We thank P. Cerný and D.J. Kontak for their comments on an earlier version of the manuscript. We also thank R.L. Linnen and D.J. Tempelman-Kluit for their constructive reviews, and D.J. Kontak and R.F. Martin for their editorial work. The field research was conducted under the auspices of the Science Institute of the Northwest Territories. Financial support was provided by the Natural Sciences and Engineering Research Council of Canada (Research Grants to LAG and MR), by the Canadian Museum of Nature (RAC grant to TSE), and by the Department of Indian Affairs and Northern Development (Yellowknife), the Canada-Yukon Mineral Development Agreement, and Canamera Geological Limited.

\section{REFERENCES}

ČERNY, P. (1975): Alkali variations in pegmatitic beryl and their petrogenetic implications. Neues Jahrb. Mineral., Abh. 123, 198-212.

(1992): Regional zoning of pegmatite populations and its interpretation. Mitt. Österr. Mineral. Ges. 137, 99107.

\& BuRT, D.M. (1984): Paragenesis, crystallochemical characteristics, and geochemical evolution of micas in granitic pegmatites. In Micas (S.W. Bailey, ed.). Rev. Mineral. 13, 257-297.

\& MeINTZER, R.E. (1988): Fertile granites in the Archean and Proterozoic fields of rare-element pegmatites: crustal environment, geochemistry and petrogenetic relationships. In Recent Advances in the Geology of GraniteRelated Mineral Deposits (R.P Taylor \& D.F. Strong, eds.). Can. Inst. Mining. Metall., Spec. Vol. 39, 170-207.

\& ANDERSON, A.J. (1985): Extreme fractionation in rare-element granitic pegmatites: selected examples of data and mechanisms. Can. Mineral. 23, 381421.

Chaudhry, M.N. \& HowIE, R.A. (1976): Lithium tourmalines from the Meldon aplite, Devonshire, England. Mineral. Mag. 40, 747-751. 
ERCIT, T.S., Wise, M.A. \& ČERnY, P. (1995): Compositional and structural systematics of the columbite group. Am. Mineral. 80, 613-619.

Foster, M.D. (1960): Interpretation of the composition of lithium micas. U.S. Geol. Surv., Prof. Pap. 354-E.

Gordey, S.P. \& ANDERSon, R.G. (1993): Evolution of the Northern Cordilleran miogeocline, Nahanni map area (105I), Yukon and Northwest Territories. Geol. Surv. Can., Mem. 428.

Holland, T.J.B. \& REDFERn, S.A.T. (1997): Unit cell refinement from powder diffraction data: the use of regression diagnostics. Mineral. Mag. 61, 65-77.

Huffman, M., NAVRotsky, A. \& Pintchovski, F.S. (1986): Thermochemistry and structure of low pressure chemically vapor deposited and bulk $\mathrm{SiO}_{2}-\mathrm{P}_{2} \mathrm{O}_{5}$ and $\mathrm{SiO}_{2}-\mathrm{GeO}_{2}$ glasses. J. Electrochem. Soc. 133, 431-439.

JAHNS, R.H. \& BURNHAM, C.W. (1969): Experimental studies of pegmatite genesis. I. A model for the derivation and crystallization of granitic pegmatites. Econ. Geol. 64, 843-864.

KEPPLER, H. (1993): Influence of fluorine on the enrichment of high field strength trace elements in granitic rocks. Contrib. Mineral. Petrol. 114, 479-488.

LeVILLAIN, C. (1980): Statistical study of $(\mathrm{OH}+\mathrm{F})$ content of muscovites, biotites and lithium micas. Tschermaks Mineral. Petrogr. Mitt. 27, 209-223.

LINNEN, R.L. (1998): The solubility of $\mathrm{Nb}-\mathrm{Ta}-\mathrm{Zr}-\mathrm{Hf}-\mathrm{W}$ in granitic melts with $\mathrm{Li}$ and $\mathrm{Li}+\mathrm{F}$ : constraints for mineralization in rare-metal granites and pegmatites. Econ. Geol. 93, 1013-1025.

LONDON, D. (1987): Internal differentiation of rare-element pegmatites: effects of boron, phosphorus and fluorine. Geochim. Cosmochim. Acta 51, 403-420.

(1995): Geochemical features of peraluminous granites, pegmatites, and rhyolites as sources of lithophile metal deposits. In Magmas, Fluids and Ore Deposits (J.F.H. Thompson, ed.). Mineral. Assoc. Can., Short-Course Handbook 23, 175-202.

(1999): Melt boundary-layers and the growth of pegmatite textures. Can. Mineral. 37, 826-827.

Morgan, G.B., VI \& HeRvig, R.L. (1989): Vaporundersaturated experiments with Macusani glass $+\mathrm{H}_{2} \mathrm{O}$ at $200 \mathrm{MPa}$, and the internal differentiation of granitic pegmatites. Contrib. Mineral. Petrol. 102, 1-17.

Martin, R.F. (1982): Quartz and the feldspars. In Granitic Pegmatites in Science and Industry (P. CERNY, ed.). Mineral. Assoc. Can., Short-Course Handbook 8, 41-62.
Mauthner, M.H.F., Mortensen, J.K., Groat, L.A. \& Ercit, T.S. (1994): Geochronology of the Little Nahanni Pegmatite Group, Selwyn Mountains, southwestern Northwest Territories. Can. J. Earth Sci. 32, 2090-2097.

Mulja, T., Williams-Jones, A.E., Wood, S.A. \& Boily, M. (1995): The rare-element-enriched monzogranite pegmatite - vein systems in the Preissac-Lacorne batholith, Quebec. I. Geology and mineralogy. Can. Mineral. 33, 793-815.

O’Connor, P.J., Gallagher, V. \& Kennan, P.S. (1991): Genesis of lithium pegmatites from the Leinster granite margin, southeast Ireland: geochemical constraints. Geol. J. 26, 295-305.

Pouchou, J.L. \& Pichoir, F. (1991): Quantitative analysis of homogeneous or stratified microvolumes applying the model "PAP". In Electron Probe Quantitation (K.F.J. Heinrich \& D.E. Newbury, eds.). Plenum Press, New York, N.Y. (31-75).

Selway, J.B., Černy, P., Hawthorne, F.C. \& Novák, M. (2000): The Tanco pegmatite at Bernic Lake, Manitoba. XIV. Internal tourmaline. Can. Mineral. 38, 877-891.

Stewart, D.B. (1978): Petrogenesis of lithium-rich pegmatites. Am. Mineral. 63, 970-980.

Tomascak, P.B., Krogstad, E.J. \& WaLker, R.J. (1998): Sm$\mathrm{Nd}$ isotope systematics and the derivation of granitic pegmatites in southwestern Maine. Can. Mineral. 36, 327-337.

TRUEMAN, D.L. \& ČERNY, P. (1982): Exploration for rare-element granitic pegmatites. In Granitic Pegmatites in Science and Industry (P. Černý, ed.). Mineral. Assoc. Can., ShortCourse Handbook 8, 463-493.

VEKLER, I.V. \& ThOMAS, R. (2002): An experimental study of B-, P- and F-rich synthetic granite pegmatite at 0.1 and 0.2 GPa. Contrib. Mineral. Petrol. 143, 673-683.

\& SchmidT, C. (2002): Experimental evidence of three coexisting immiscible fluids in synthetic granitic pegmatite. Am. Mineral. 87, 775-779.

Webber, K.L., Simmons, W.B., FAlster, A.U. \& Foord, E.E. (1999): Cooling rates and crystallization dynamics of shallow level pegmatite-aplite dikes, San Diego County, California. Am. Mineral. 84, 708-717.

Young, R.A., Sakthivel, A., Moss, T.S. \& Paiva-Santos, C.O. (1995): DBWS-9807 (1995): DBWS-9411, an upgrade of the DBWS ** programs for Rietveld refinement with PC and mainframe computers. J. Appl. Crystallogr. 28, 366-367.

Received September 1, 2001, revised manuscript accepted January 25, 2003. 